
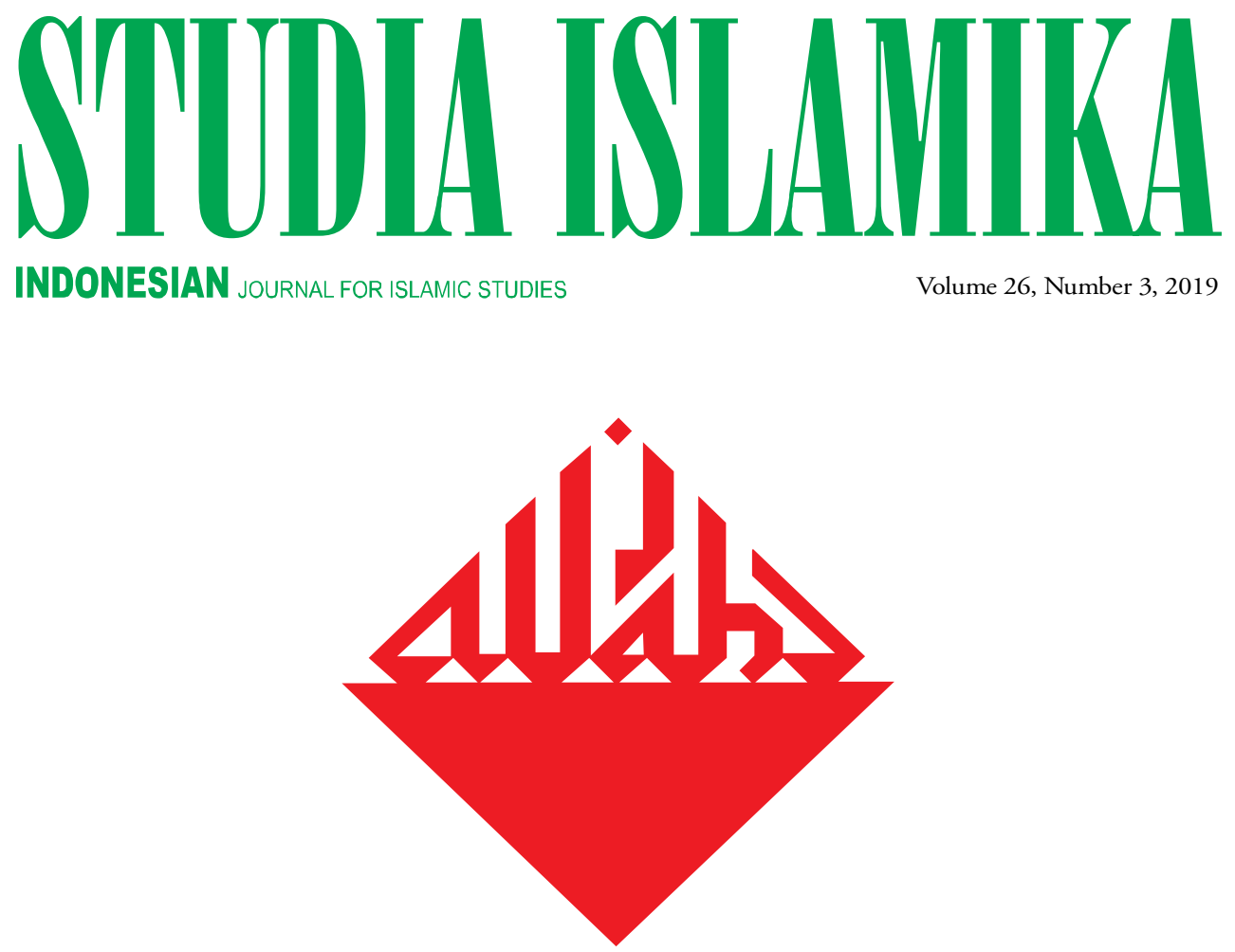

Pretext for Religious Violence in Indonesia: An Anthropolinguistic Analysis of Fatwas on Ahmadiyya Fariz Alnizar

Food and Local Social Harmony:

Pork, Communal Dining, and Muslim-Christian Relations in Flores, Indonesia Yohanes S. Lon \& Fransiska Widyawati

Religious Pluralism Revisited: Discursive Patterns of the Ulama Fatwa IN INDONESIA AND Malaysia Syafiq Hasyim

The Decline of Traditional Learning Methods in Changing Indonesia:

Trends of Bandongan-Kitäb Readings in Pesantrens Ervan Nurtawab 
STIUDLA ISLAMIIIKA 



\section{SIIIDIA ISLAMIIIKA}

Indonesian Journal for Islamic Studies

Vol. 26, no. 3, 2019

EDITOR-IN-CHIEF

Azyumardi Azra

MANAGING EDITOR

Oman Fathurahman

EDITORS

Saiful Mujani

Jambari

Didin Syafruddin

Jajat Burhanudin

Fuad Jabali

Ali Munhanif

Saiful Umam

Dadi Darmadi

Jajang Jahroni

Din Wahid

Euis Nurlaelawati

INTERNATIONAL EDITORIAL BOARD

M. Quraish Shihab (Syarif Hidayatullah State Islamic University of Jakarta, INDONESIA)

M.C. Ricklefs (Australian National University, AUSTRALIA)

Martin van Bruinessen (Utrecht University, NETHERLANDS)

John R. Bowen (Washington University, USA)

M. Kamal Hasan (International Islamic University, MALAYSIA)

Virginia M. Hooker (Australian National University, AUSTRALIA)

Edwin P. Wieringa (Universität zu Köln, GERMANY)

Robert W. Hefner (Boston University, USA)

Rémy Madinier (Centre national de la recherche scientifique (CNRS), FRANCE)

R. Michael Feener (National University of Singapore, SINGAPORE)

Michael F. Laffan (Princeton University, USA)

Minako Sakai (The University of New South Wales, AUSTRALIA)

Annabel Teh Gallop (The British Library, UK)

Syafaatun Almirzanah (Sunan Kalijaga State Islamic University of Yogyakarta, INDONESIA)

\section{ASSISTANT TO THE EDITORS}

Testriono

Muhammad Nida' Fadlan

Abdullah Maulani

ENGLISH LANGUAGE ADVISOR

Benjamin J. Freeman

Daniel Peterson

Batool Moussa

ARABIC LANGUAGE ADVISOR

Tb. Ade Asnawi

\section{COVER DESIGNER}

S. Prinka 
STUDIA ISLAMIKA (ISSN 0215-0492; E-ISSN: 2355-6145) is an international journal published by the Center for the Study of Islam and Society (PPIM) Syarif Hidayatullah State Islamic University of Jakarta, INDONESIA. It specializes in Indonesian Islamic studies in particular, and Southeast Asian Islamic studies in general, and is intended to communicate original researches and current issues on the subject. This journal warmly welcomes contributions from scholars of related disciplines. All submitted papers are subject to double-blind review process.

STUDIA ISLAMIKA has been accredited by The Ministry of Research, Technology, and Higher Education, Republic of Indonesia as an academic journal (Decree No. 32a/E/KPT/2017).

STUDIA ISLAMIKA has become a CrossRef Member since year 2014. Therefore, all articles published by STUDIA ISLAMIKA will have unique Digital Object Identifier (DOI) number.

STUDIA ISLAMIKA is indexed in Scopus since 30 May 2015.

Editorial Office:

STUDIA ISLAMIKA, Gedung Pusat Pengkajian

Islam dan Masyarakat (PPIM) UIN Jakarta,

Jl. Kertamukti No. 5, Pisangan Barat, Cirendeu,

Ciputat 15419, Jakarta, Indonesia.

Phone: (62-21) 7423543, 7499272, Fax: (62-21) 7408633;

E-mail: studia.islamika@uinjkt.ac.id

Website: http://journal.uinjkt.ac.id/index.php/studia-islamika

Annual subscription rates from outside Indonesia, institution: US\$ 75,00 and the cost of a single copy is US\$ 25,00; individual: US\$ 50,00 and the cost of a single copy is US\$ 20,00 . Rates do not include international postage and handling.

Please make all payment through bank transfer to: PPIM, Bank Mandiri KCP Tangerang Graha Karnos, Indonesia, account No. 101-00-0514550-1 (USD),

Swift Code: bmriidja

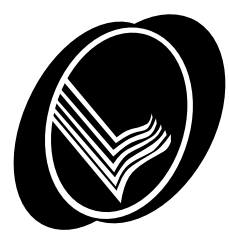

Harga berlangganan di Indonesia untuk satu tahun, lembaga: Rp. 150.000,-, harga satu edisi Rp. 50.000,-; individu: Rp. 100.000,-, harga satu edisi Rp. 40.000,-. Harga belum termasuk ongkos kirim.

Pembayaran melalui PPIM, Bank Mandiri KCP Tangerang Graha Karnos, No. Rek: 128-00-0105080-3 


\section{Table of Contents}

\section{Articles}

417 Fariz Alnizar

Pretext for Religious Violence in Indonesia:

An Anthropolinguistic Analysis

of Fatwas on Ahmadiyya

445 Yohanes S. Lon \& Fransiska Widyawati

Food and Local Social Harmony:

Pork, Communal Dining, and Muslim-Christian

Relations in Flores, Indonesia

475 Syafiq Hasyim

Religious Pluralism Revisited:

Discursive Patterns of the Ulama Fatwa

in Indonesia and Malaysia

511 Ervan Nurtawab

The Decline of Traditional Learning Methods

in Changing Indonesia:

Trends of Bandongan-Kitāb Readings in Pesantrens

543 Jamaluddin

Al-Shabakāt al-ijtimā‘̄ìyah wa al-fikrīyah

bayn muslimī Lombok wa Sumatera:

Dirāsah fī tuḥfah wa makhṭūṭ Sasak 


\section{Book Review}

585 Muhammad Nida' Fadlan

Lebih dari Sekedar Katalog Manuskrip:

Jejak Intelektualisme Islam di Mindanao

\section{Document}

603 Ismatu Ropi

Whither Religious Moderation?

The State and Management of

Religious Affairs in Contemporary Indonesia 


\title{
Jamaluddin
}

\section{Al-Shabakāt al-ijtimāīiyah wa al-fikrīyah bayn muslimī Lombok wa Sumatera: Dirāsah fī tuḥfah wa makhțūt Sasak}

\begin{abstract}
This article discusses the socio-intellectual networking of Indonesian Muslim communities, especially in Sumatra and Lombok communities. The relationship between them is observed through ancient manuscripts and artifacts, while the philological and archeological approach are utilized to reconstruct its history. From these two primary sources, this article finds that the Sumatra-Lombok relationship had long existed and both of them had been influencing one another. One of the pieces of evidence held by the Sasak People in West Nusa Tenggara proves this infuence existence. It is also supported by the existence of Malay-language manuscripts which are currently kept by the Sasak people. Supporting the written evidence, archaeological evidence also espouses the article's argument wherein it can be found from the presence of Aceh's gravestones found in Raja Selaparang's burial complex in Lombok, West Nusa Tenggara. On the basis of these two historical sources, the article proves that the connectedness of the Sumatran-Lombok community had existed before the era of the Islamic kingdom in the Nusantara. When the emergence of the Islamic empire, the relationship between the two was even further strengthened by the presence of the scholars from both regions who came and settled in Mecca.
\end{abstract}

Keywords: History, Malay, Sasak, Manuscript, Artifact. 
Abstrak: Artikel ini mendiskusikan jaringan sosial intelektual masyarakat muslim Indonesia, khususnya Sumatera dengan Lombok. Hubungan keduanya dilihat melalui manuskrip-manuskrip dan artefak kuno sehingga digunakan pendekatan filologis dan arkeologis untuk merekonstruksi sejarahnya. Dari kedua sumber primer tersebut, artikel ini menemukan bahwa hubungan Sumatera-Lombok telah lama terjalin dan keduanya saling mempengaruhi satu sama lain. Pengaruh tersebut dapat ditemukan dari bukti-bukti yang dipegang oleh masyarakat suku Sasak di Nusa Tenggara Barat. Bukti yang menjelaskan hal tersebut diantaranya adalah keberadaan manuskrip-manuskrip berbahasa Melayu yang hingga saat ini disimpan oleh masyarakat Sasak. Selain bukti tertulis, bukti arkeologis yang mendukung argumentasi tersebut diperkuat dengan keberadaan batu nisan Aceh yang ditemukan di komplek pemakaman Raja Selaparang di Lombok, Nusa Tenggara Barat. Atas dasar dua fakta sejarah tersebut, artikel ini membuktikan bahwa keterhubungan masyarakat Sumatera-Lombok telah terjalin sebelum era kerajaan Islam di Nusantara. Ketika kemunculan kerajaan Islam, hubungan keduanya semakin diperkuat dengan keberadaan para ulama dari kedua wilayah tersebut yang datang dan menetap di Mekkah.

Kata kunci: Sejarah, Melayu, Sasak, Manuskrip, Artefak.

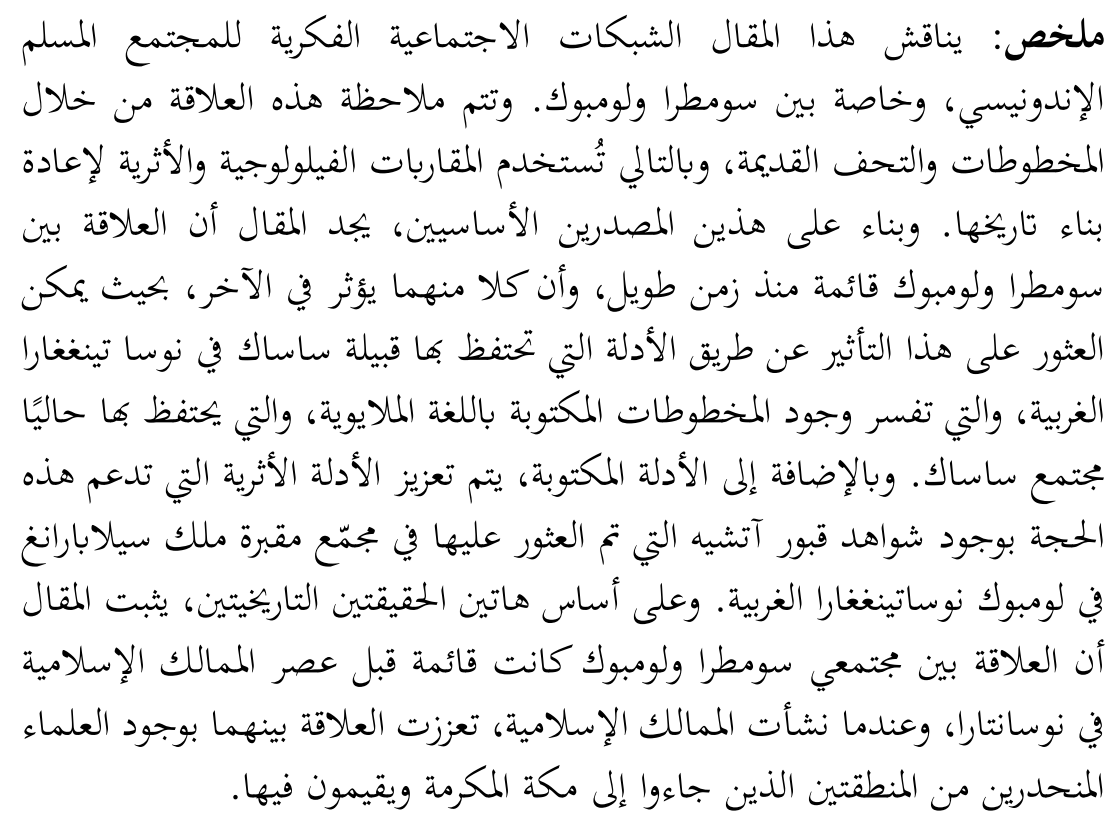

الكلمات المفتاحية: التاريخ، الملايو، ساسك، المخطوطة، التحفة. 


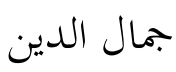

\section{الشبكايث الاجتهاعية والمنحرية}

\section{:Sumatera y Lombok بينغ هسلهيى}

\section{كasak كواسة كيم تهنة وهلطوط}

تعتبر دراسة العلاقات بين المناطق في إندونيسيا دراسة مثيرة للاهتمام، خاصة حول العلاقات بين لومبوك وسومطرة، بحيث ترجع أهميتها البالغة

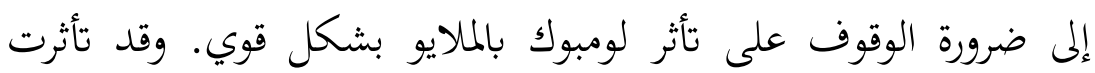

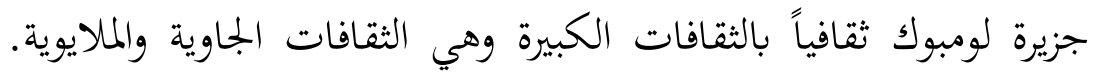

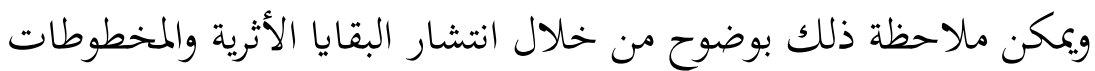
القديمة، والتي تتأثر في الغالب بهاتين الثقافتين (بالجاوية والمالايوية). أصبحت الدراسة حول لومبوك وعلاقاتحا بمناطق سومطرة دراسة مليئة

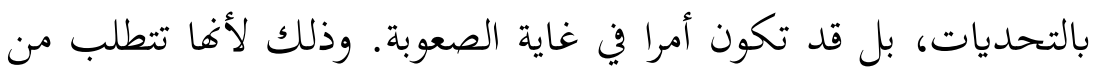

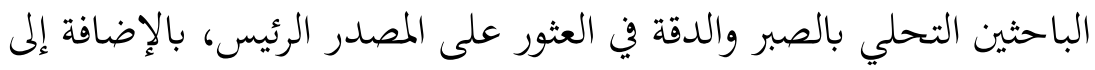

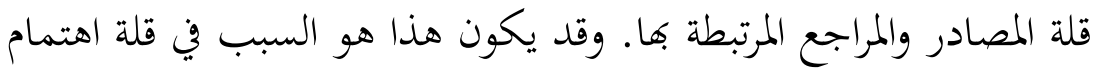

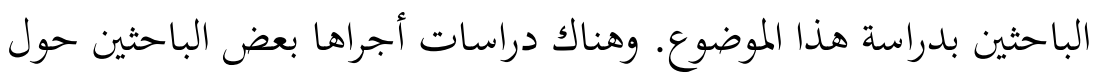


لومبوك، حيث يقولون إن ثقافة لومبوك تتأثر بشدة بجاوا وبالي Budiwanti) 61999; Nas and Boender 2002; Patji 2005; Ricklefs 2008; Syam 2005) غير أن الكاتب يرى أن الثقافات الجاوية والملايوية هي التي أثرت تأثيرا

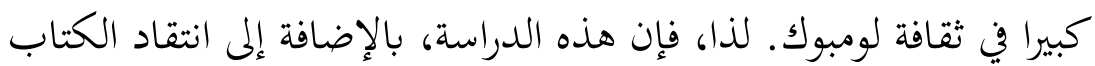
السابقين، سوف تملأ المساحة الفارغة حول الدراسة في جزيرة لومبوك. ويمكن رؤية التأثير القوي للملايو في العديد من الأشياء، أولاً، في البقايا الأثرية، مثل مجمع المقابر القديمة، والعديد من الأماكن الأخرى. ففي المقابر القديمة تم العثور على شواهد القبور التي تشبه ما هو موجود في آتشيه (Jamaluddin 2019, 148-50). وثانيا، يمكن رؤية كل من التأثيرات الملايوية في تقليد المخطوطات. وتذكر بعض الكتابات أن ثقافة لومبوك إضافة إلى تأثرها بالثقافات الجاوية والبالية والماكاسارية، فإها متأثرة كذلك بالثقافة بعافة الملايوية، لكن ليس هناك ما يكشف عن الوقت الذي وصلت فيه إلى لومبوك (Fakihuddin 2018, 94). وقد تم العثور على العديد من المخطوطات القديمة في لومبوك، ومن بينها المخطوطات الملايوية (Jamaluddin 2012)، حيث يمكن ملاحظة ذلك عن طريق اللغة المستخدمة وفي محتوياقا. وكذلك وكن بئك من خلال التقاليد السائدة في المجتمع التي تتأثر، بشكل كبئ كبير بالمالايو.

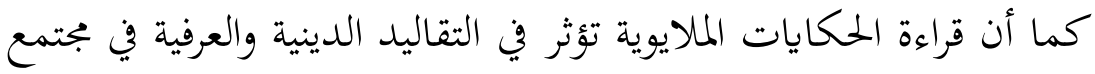

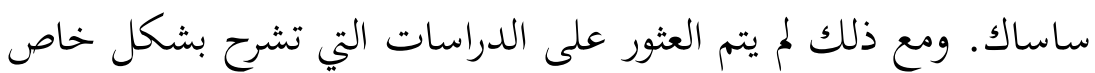

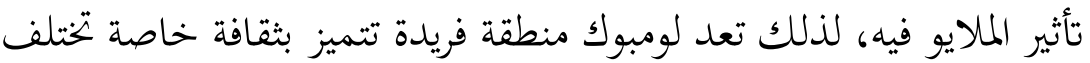

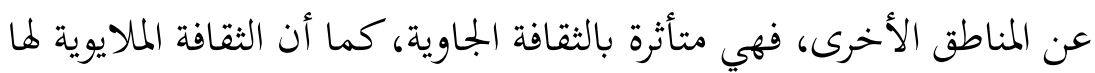
تأثير كبير في مجتمع ساساك. ولا تتوفر كتابة التاريخ المحلي خلال هذا الوقت على معايير الكتابة العلمية، وبعبارة أخرى أها لا تستخدم الطريقة المطلوبة في كتابته. ويتجلى إنى ذلك في عدم استخدام المصادر الموثوقة مثل المخطوطات التي تعتبر بمثابة 
الأعمال الفكرية المحلية (Nordholt 2008, 1)، وبالتالي فإن النتائج المصصل عليها لا يمكن وصفها بأهما عمل تاريخي.

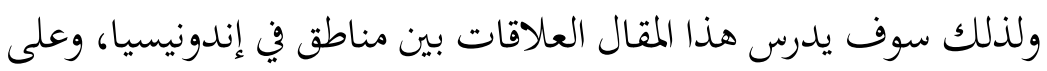

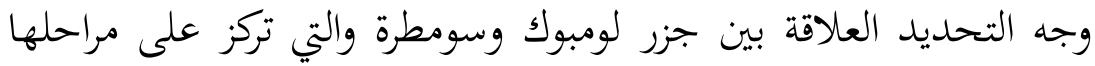

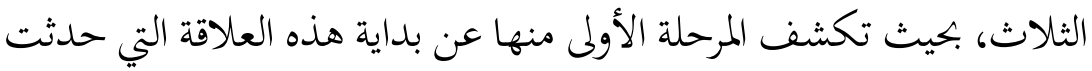

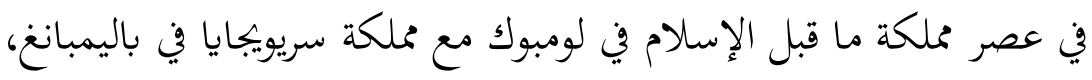

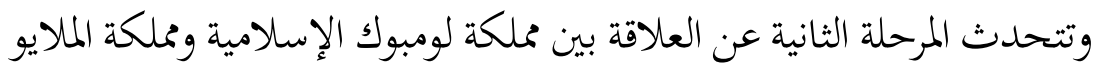

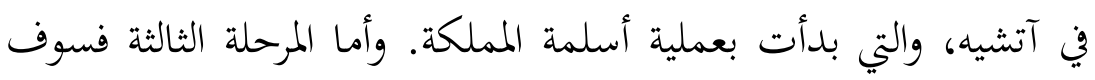

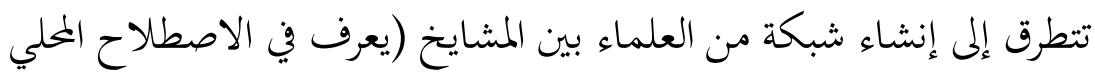

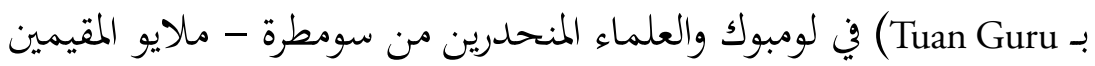
في بلد الحرمين الشريفين. أما المصادر المستخدمة في هذه الدراسة فهي مصدران رئيسان، وهمان

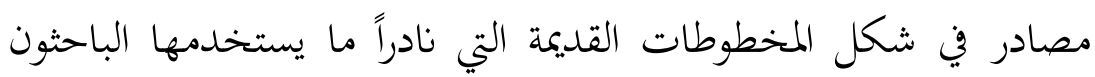

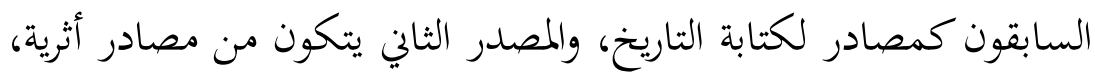

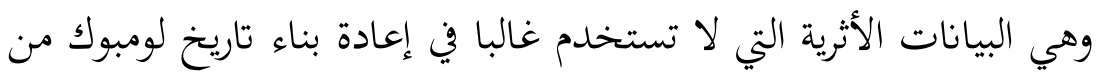

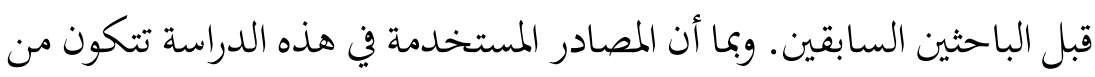

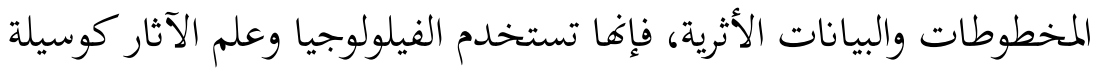
مساعدة في إعادة بناء تاريخ العلاقة بين لومبوك وسومطرا.

\section{العلاقة المبكرة: مملكة لومبوك و مملكة سريويجايا}

تقع جزر الأرخبيل (نوسانتارا) على طريق التجارة العالمية كمنطقة وسيطة

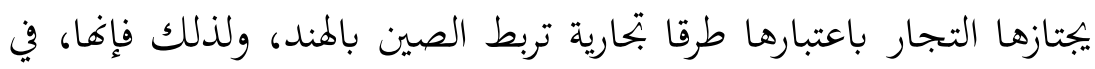

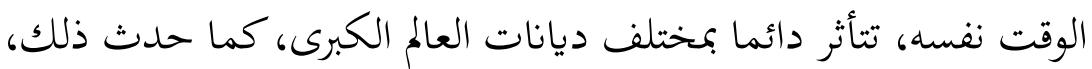
على الأقل، في مناطق الجزر الواقعة على خط ساحلى دائل البحان البحر الجاوي التي 
كان للهندوسية والبوذية تأثير قوي فيها منذ حوالي القرنين الخامس والثامن الميلاديين، حيث ينعكس ذلك بوضوح في التقاليد السائدة في الجمتمع. وتعتبر لومبوك جزءا من جزر الأرخبيل التي كانت تشارك مع غيرها من بن بن الجزر في التجارة العالمية. وبحكم موقعها على طريق التجارة فإذا تشارك

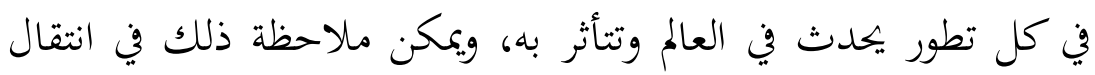
الدين الذي حدث في مجتمع ساساك. فعندما تسيطر مملكة سريويجايا التي تعتنق الديانة البوذية على الطريق التجاري، فإن بجتمع لومبوك يعتنق

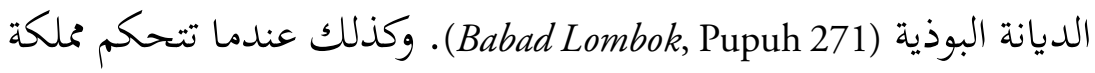
ماجاباهيت التي تعتنق الديانة الهندوسية على طريق التجارة، فإن المجتمع يعتنق الديانة الهندوسية (Babad Lombok, Pupuh 265). لذا، نظرًا لموقعها على طريق التجارة العالمية، فإغاا متأثرة دائمًا بالتطورات العالمية التي تحدث على هذا الطريق التجاري. وقد أقامت المملكة في لومبوك العلاقات المبكرة

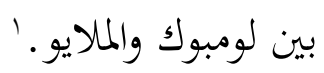
وتعد محلكة لومبوك أكبر الممالك وأكثرها ديناميكية. وهناك العديد من

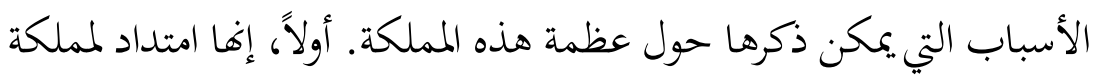
سوونغ Suwung، والتي منذ البداية، تم الاعتراف بوجودها من قبل الممالك

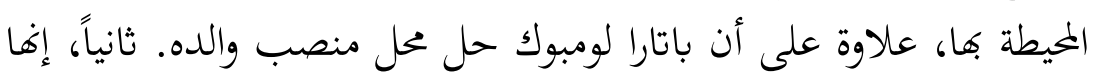
مملكة ساحلية تقع بالقرب من الساحل الشرقي لجزيرة لومبوك، حيث يوجد في لومبوك ميناء يصبح بوابة متصلة بين محلكة لومبوك والعالم الخارجي، كما يعدّ يُّل (Babad Lombok, هذا الميناء نافذة للتواصل بشكل مباشر مع الدول الأخرى .Pupuh 47) (Jamaluddin 2004, 285-88) وبالإضافة إلى ذلك فإن محلكة لومبوك هي محلكة ساحلية أو بحرية، حيث تسيطر على مضيق لومبوك. وأصبح ميناء لومبوك مدينة بتارية، ويعتبر طريقا بحاريا استراتيجيا للغاية مزدحما بالسفن التجارية. وكان تطور 
المملكة الساحلية متأثرا إلى حد كبير بالتجارة العالمية في جنوب شرقي

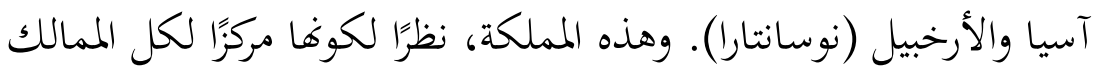

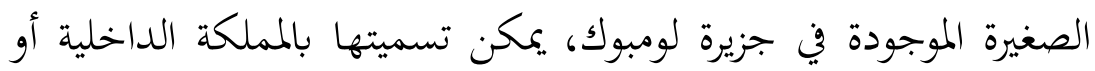

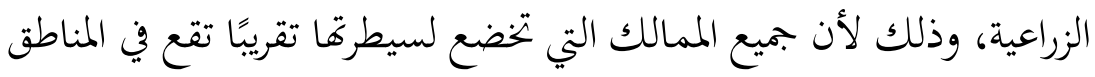

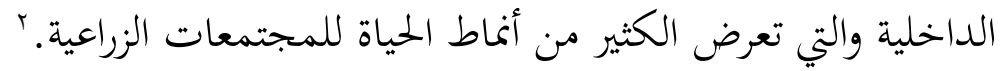

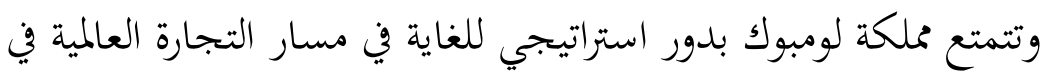

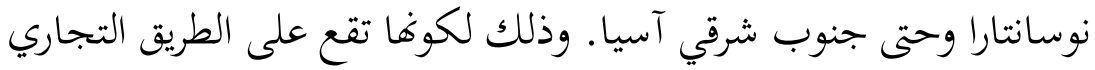

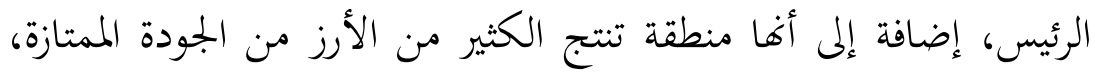

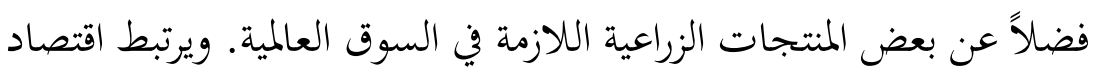

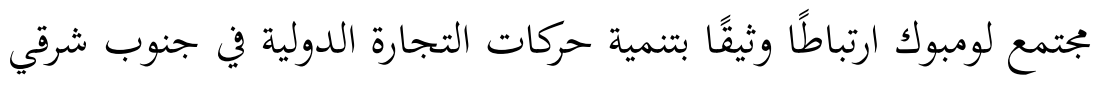

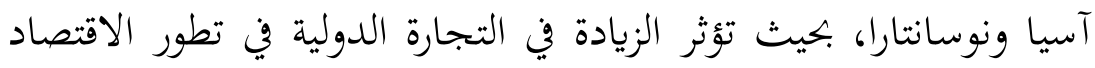

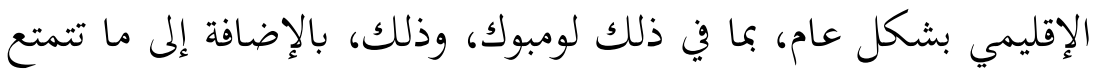

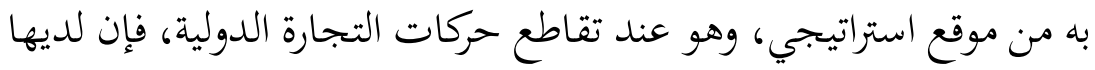

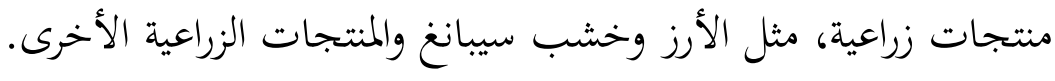

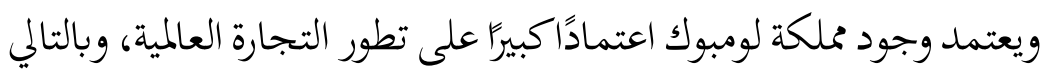

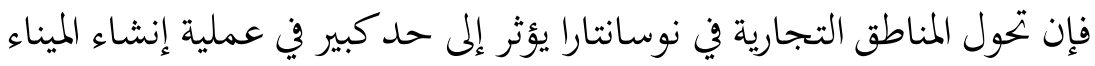

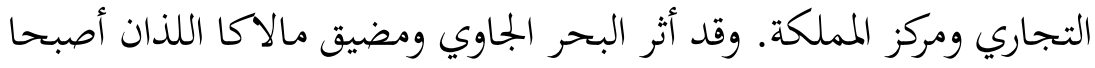

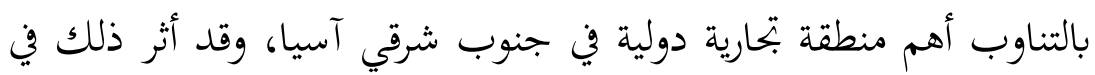

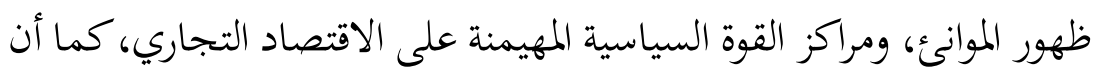

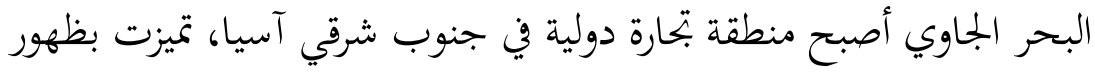

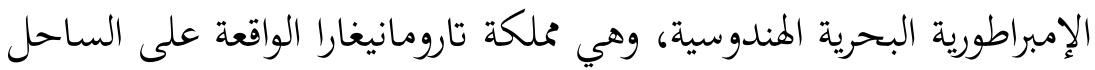

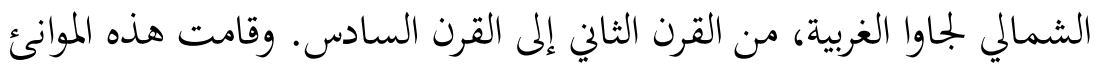

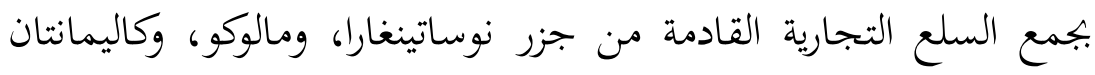

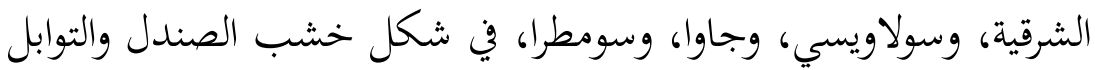


(القرنفل). وبعد ذلك حل مضيق مالاكا ححل البحر الجاوي في دوره كمنطقة بتحارية دولية من القرن السابع إلى القرن الحادي عشر، حيث تم من خلال هذه الفترة إنشاء الميناء الدولي للإمبراطورية البحرية البوذية وهي محلكة سريويجايا.

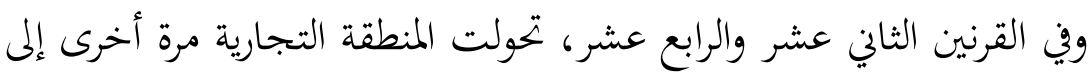
البحر الجاوي، وانتقلت هيمنة التجارة الدولية من سريويجايا إلى أيدي القوة البحرية الزراعية الهندوسية-البوذية، وهي محلكة ماجاباهيت. كما تسبب البعابته اهيار القوة السياسية لمملكة ماجاباهيت في القرن الخامس عشر في اهيه اهيار هيمنتها على التجارة الدولية، حيث ظهر منذ ذلك الحين عهد جديد في أنشطة التجارة الدولية في جنوب شرقي آسيا ونوسانتارا، وهو عصر التجارة

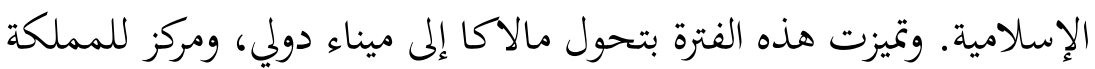
الإسلامية التي تسيطر على التجارة الدولية في مضيق مالاكا. وبعد نشأة

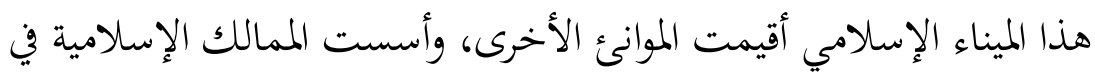
نوسانتارا (Suryo 2005, 273). وقد أقامت لومبوك بشكل مكثف العلاقات مع جاوا في عصر محلكة ماجاباهيت البوذية المندوسية. وكان التجار الجاويون المتجهون نهو سولاويسي ومالوكو يجعلون ميناء لومبوك كنقطة عبور، وتوفير إمدادات الرحلة. وكذلك كانوا يشترون الأرز من التجار الموجودين في لومبوك عندما عرفوا أن هذه

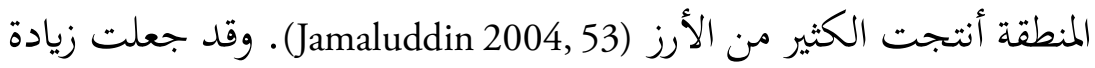
وسائل النقل، وكثرة زيارة التجار القادمين من الأماكن المختلفة لمدن الموانئ جعلت التواصل والعلاقات بين الجزر أكثر تقدما. وهكذا فإن العلاقة التي أقامتها الممالك في لومبوك لا تقتصر على الجزر المجاورة، وإنما أقامت كذلك علاقات بتارية مع باليمبانغ في سومطرا (Jamaluddin 2004).

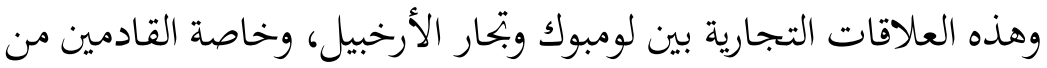
جزر سومطرا، كل ذلك يمكن ملاحظته من خلال المصادر التاريخية التقليدية 
لجزيرة لومبوك. وقد ذكر مصدر لومبوك النزاع الذي حدث بين وزير برانغبانتون (Patih Brangbantun)

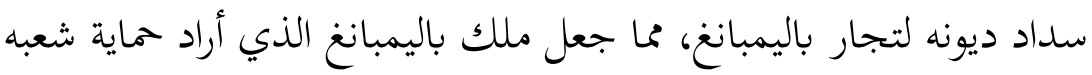

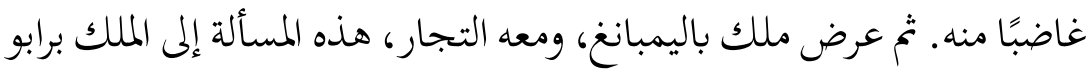

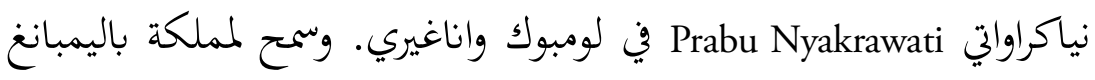

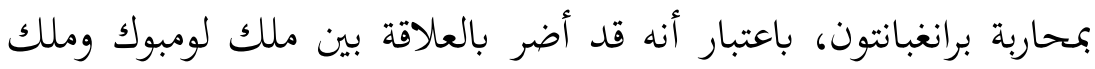

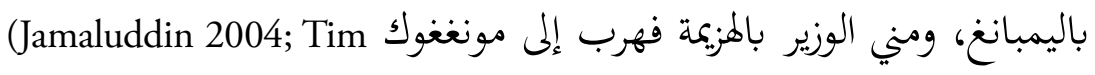
.Penyusun 1977, 11)

وتبين مما سبق أن ملك لومبوك قد أقام علاقات دبلوماسية مع ملك

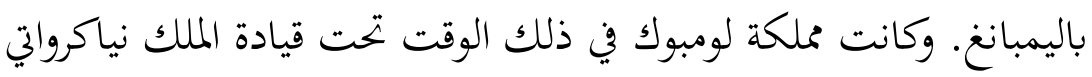

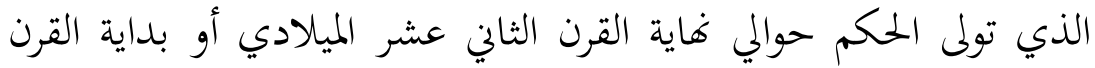

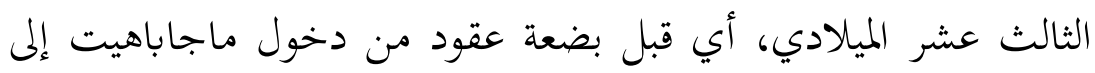

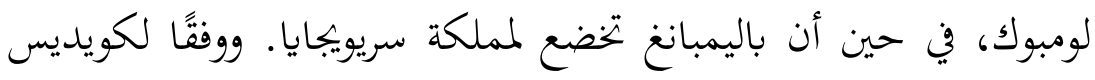
Coede’s

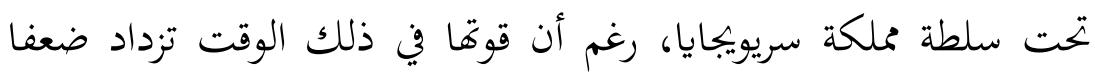
.(Coede's 2015, 246-47)

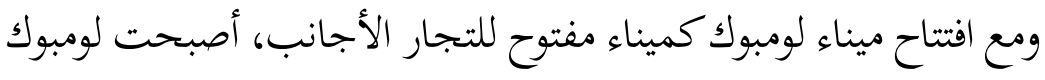

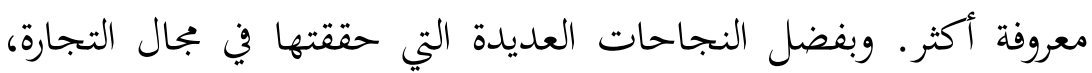

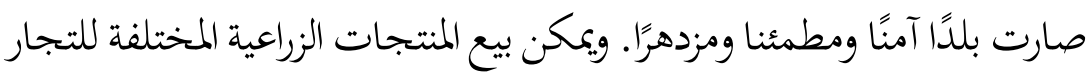

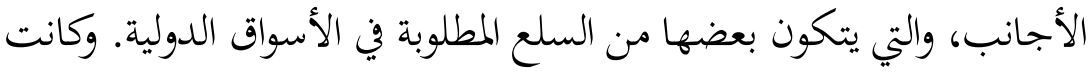

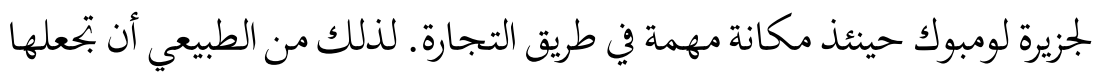

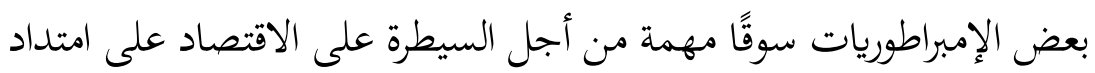
طريق التجارة أو لأغراض أخرى. 


\section{العلاقات بين لومبوك وسومطرا في عصر محلكة سيلابارانغ}

تعد سيلابارانغ Selaparang مملكة مشهورة، سواء في لومبوك أو خارجها. ويتضح ذلك من خلال استخدام سيلابارانغ اسما للعديد من الأماكن،

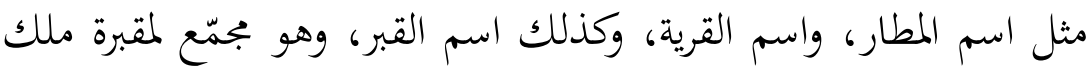

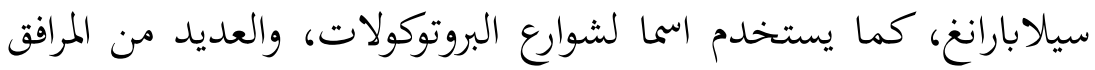

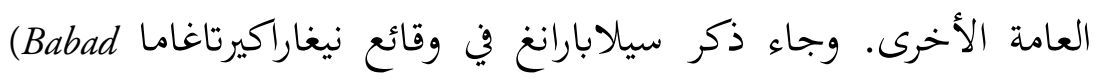
Segarakertagama) كبيرا في عصور الازدهار لمملكة ماجاباهيت (Jamaluddin 2019).

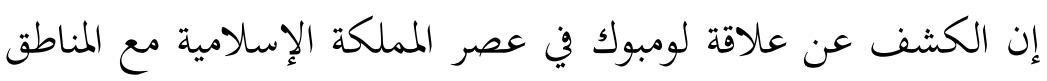

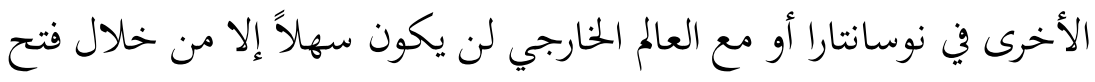

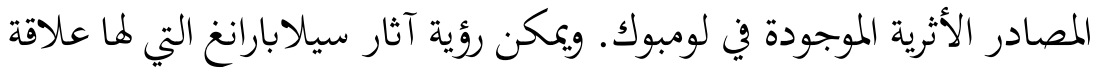

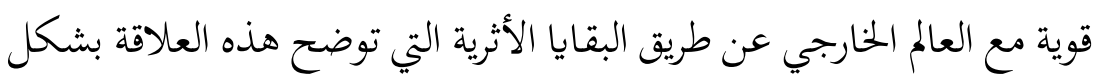

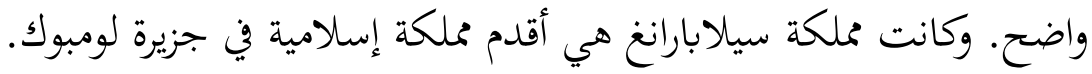

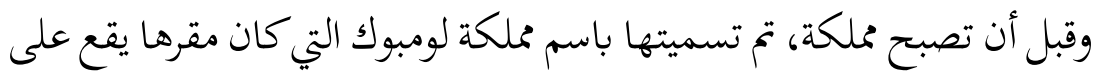

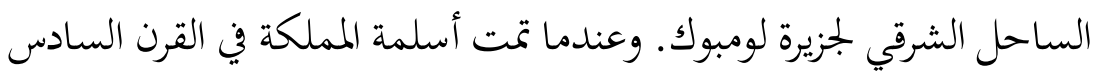

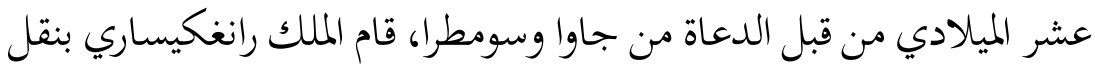

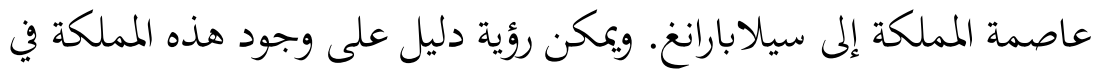

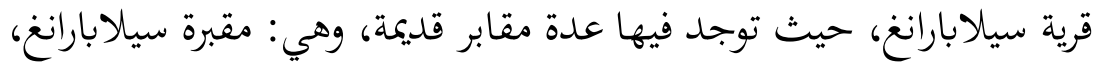

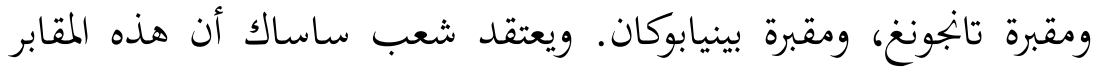

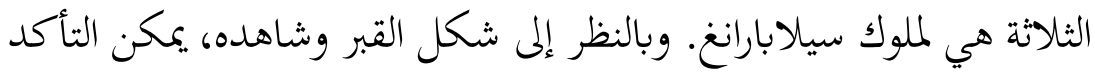

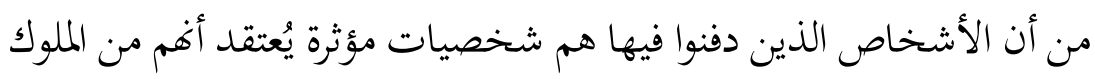

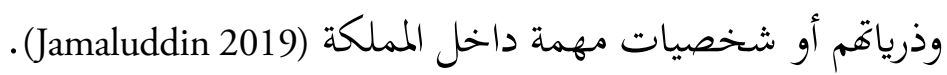

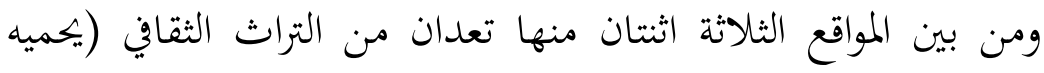

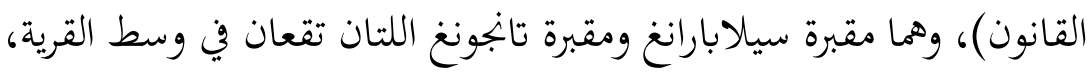


بينما يقع الآخر على بعد كيلومترين إلى الشرق، حيث توجد مقبرة لا

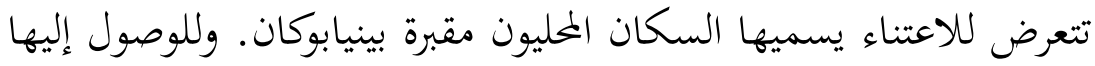
من جهة الطريق الرئيس برينغغابايا- سويلا ينبغي المشي على الأقدام على يلى بعد حوالي ثلامائة مترا عبر ممر ضيق (Jamaluddin 2019).

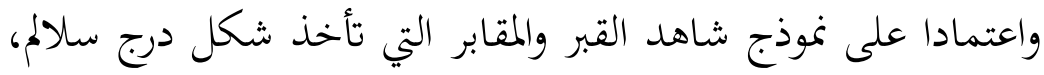
فإنه من المؤكد أن لومبوك تتأثر أيضًا بثقافات ما قبل الإسلام التي كانت

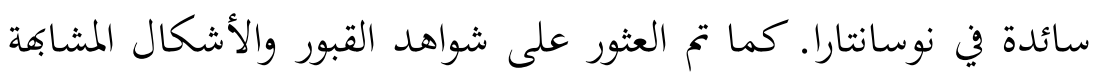
في أماكن أخرى، مثل سولاويسي، وسومطرةا، وجاوا، والعديد من الأماكن

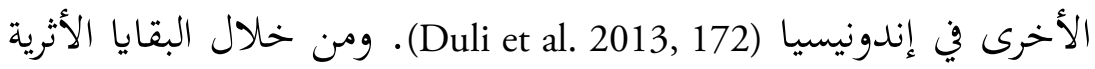
تظهر أوجه التشابه في الثقافات، والتقاليد، والمراحل التاريخية، وغيرها، بحيث يشير ذلك إلى أن لومبوك لديها علاقات قوية مع المناطق الأخرى في نوسانتارا.

وتعد مراسيم الجنازة من التعاليم الإسلامية، وهي فرض كفاية يجب أن

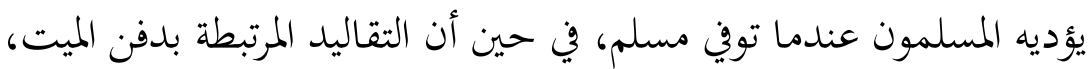
ونماذج القبور وأشكالها لا تزال متأثرة بالتقاليد الهندوسية والبوذية، وبالتالي فإها في جميع الأماكن تقريبا تأخذ الطابع الإسلامي الخاص بإندونيسيا. ولقد بدأ بالفعل تكييف الإسلام بالثقافات المحلية من قبل الدعاة المسلمين

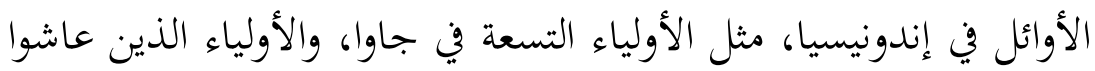
في لومبوك (Sulanam 2013a, 213). ولا يزال هناك العديد من التقاليد القديمة، طالما لا يوجد دليل يجرمها،

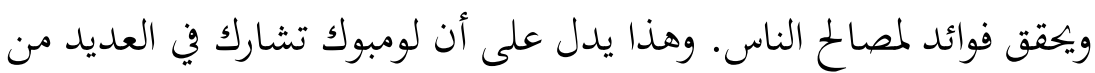
الأنشطة التي بتمع بين المناطق في نوسانتارا، وخاصة في بجال التجارة. وقد أدت هذه اللقاءات إلى ظهور أوجه التشابه في التقاليد والثقافة بين المناطق

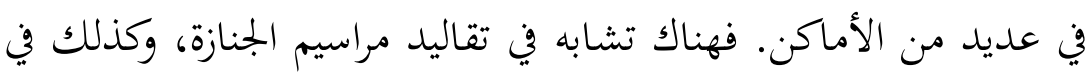


التقاليد الأخرى، ومن الأمثلة التي يمكن ذكرها تقاليد الاحتفال بالمولد

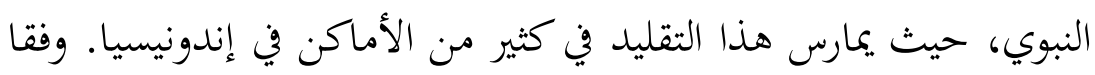

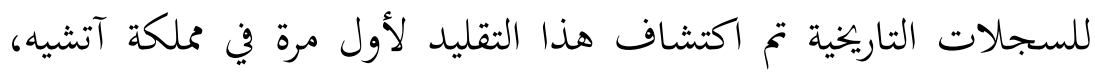

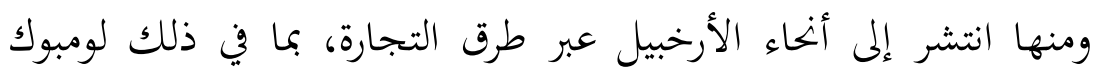
.(Jamaluddin 2011a) وذُكر في مخطوط ساسك أن الذين جاءوا للقيام بأسلمة مجتمع ساساك هم

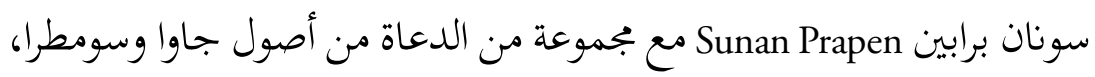

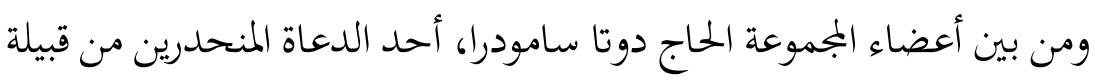
الملايو الذي كان مبعوثا لمملكة باليمبانغ (549-548 (Babad Lombok, Pupuh

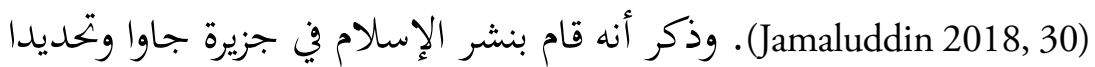

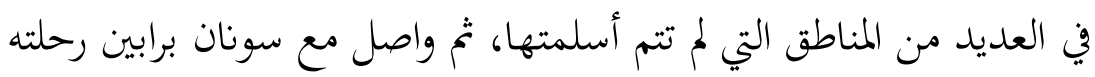

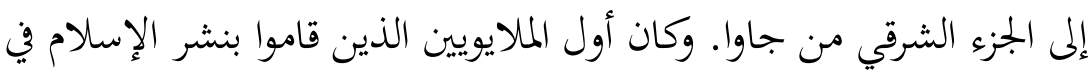

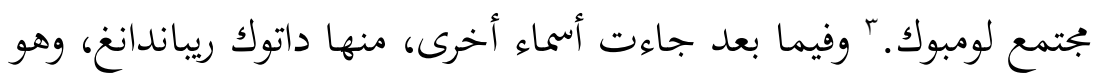

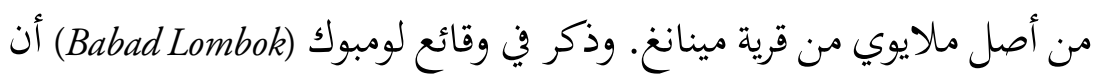

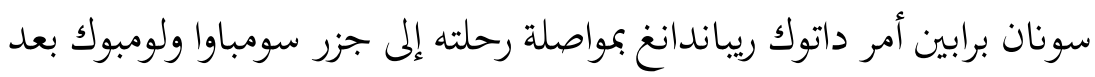

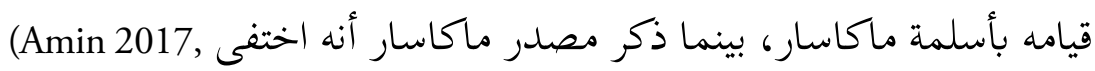
(175، مع أنه واصل رحلته إلى لومبوك. ويعتبر هؤلاء الأشخاص من من الماكلايويين

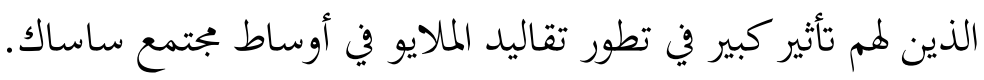

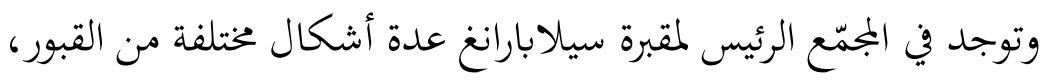

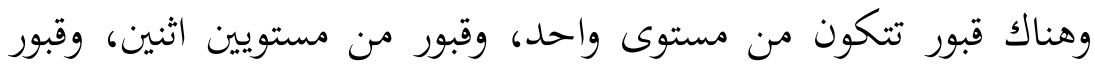

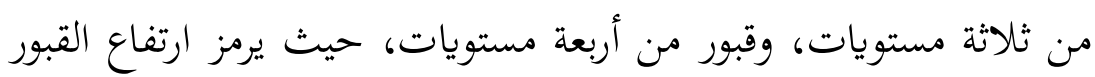

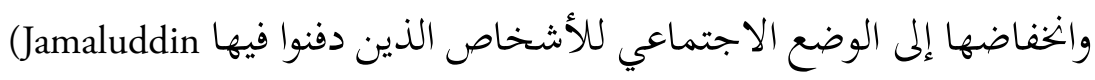

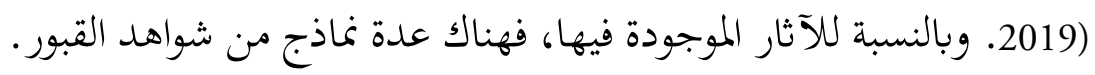

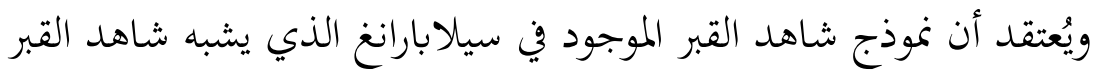


في آتشيه هو نموذج قبر آتشيه في القرن السادس عشر تقريبًا. وهناك أيضًا

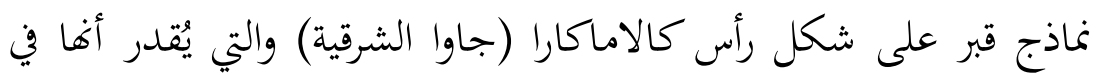

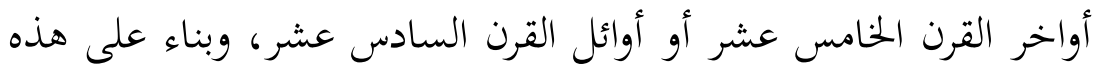

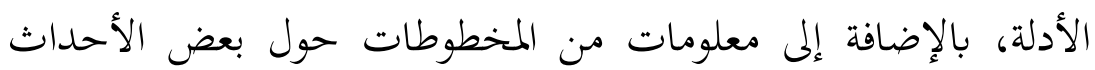

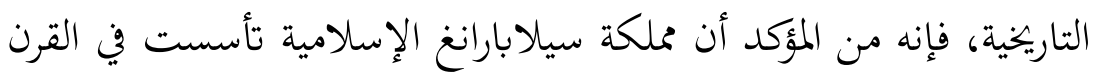
السادس عشر الميلادي.

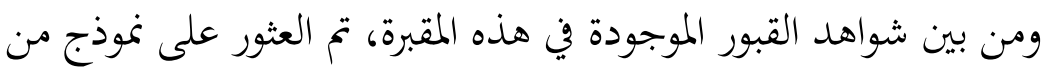

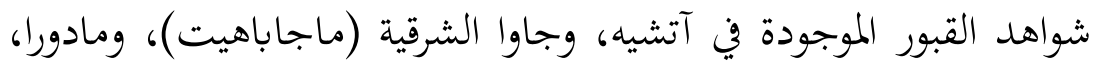

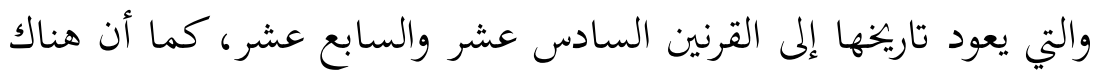

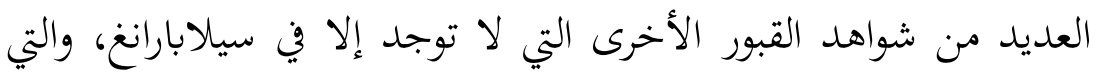

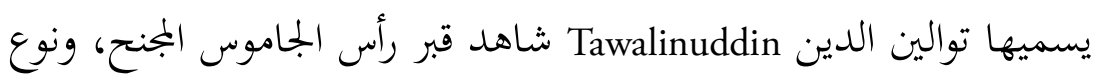
سيليندريك (Haris 2002, 17). وتتميز العلاقة بين لومبوك والمناطق الأخرى، مثل جاوا الشرقية، وسومطرا

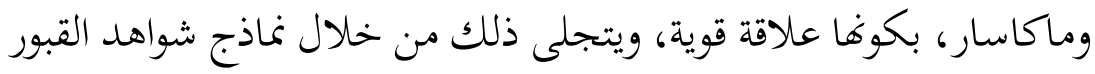

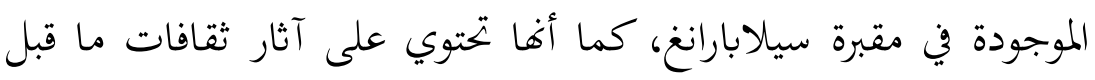

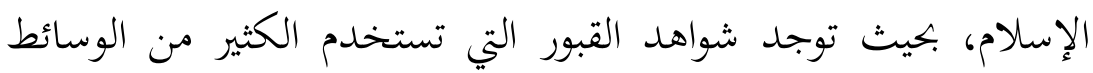
النباتية وأشكال المعابد.

وتشير نماذج شواهد القبور الموجودة فيها إلى أن الإسلام في لومبوك يرتبط الماتئ

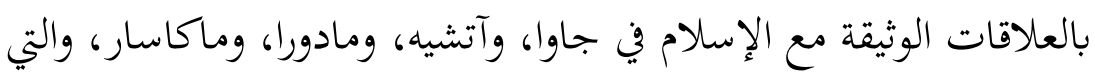

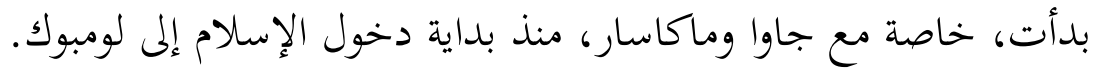

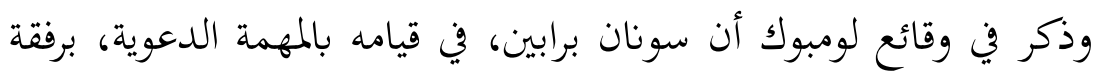

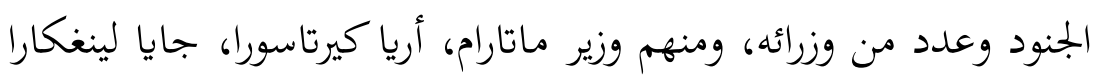

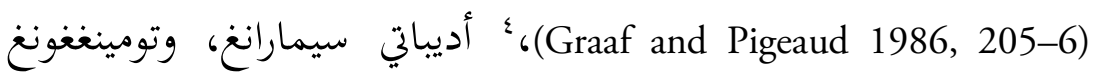

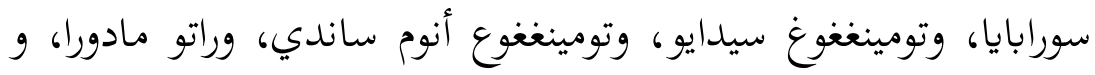




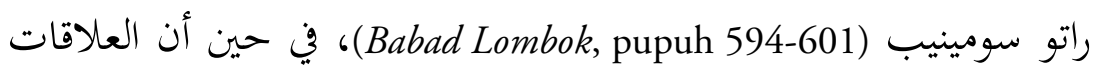

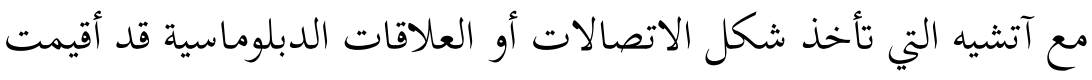

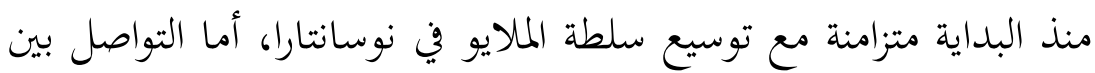

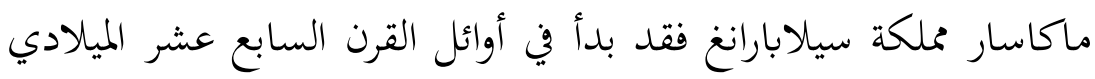
.(Jamaluddin 2019)

وكانت محلكة سيلابارانغ تلعب دوراً حاسماً في انتشار الإسلام، وفي

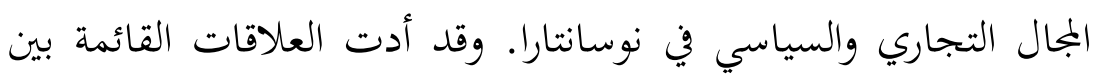

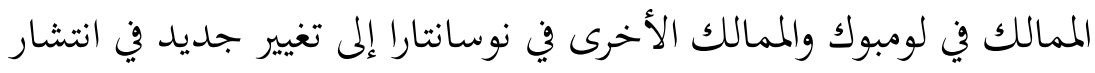

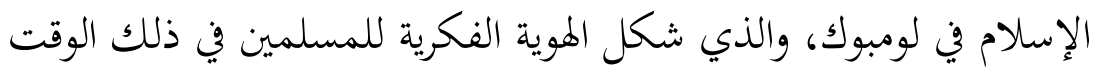
وكذلك للأجيال للاحقة.

وكانت سيطرة مملكة سيلابارانغ على السلطات السياسية لا تقتصر

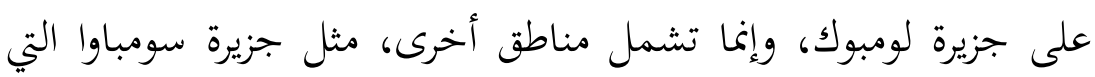

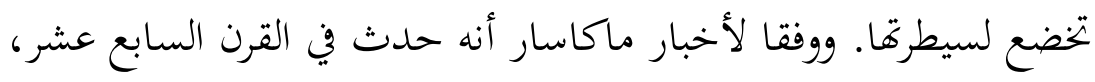

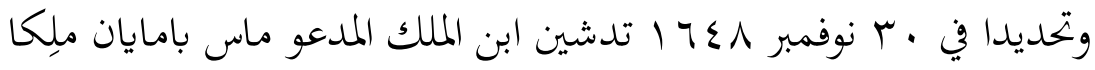

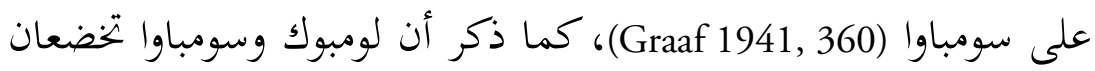
لسلكطة ملك كان مقره في لومبوك. وفي ذلك الوقت قد يكون هناك رابط أوماوك

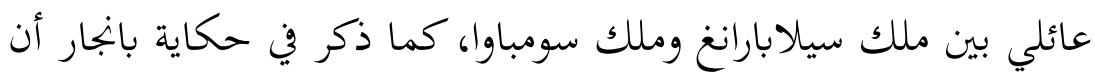

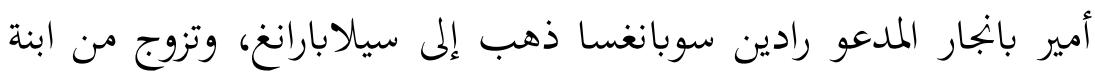

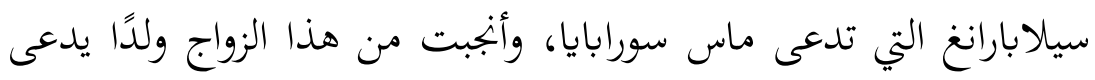

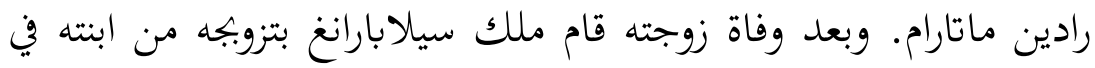

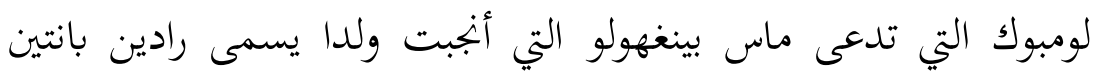
.(Handayani 1997, 83; Ras 1968)

وفيما يتعلق بالقبيلة الملايوية الموجودة في سومطرا، فإن مملكة لومبوك المان

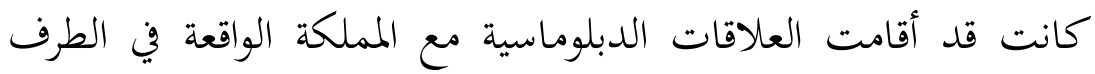


الشمالي لجزيرة سومطرا. وتم الكشف عن ذلك من خلال البقايا الأثرية التي

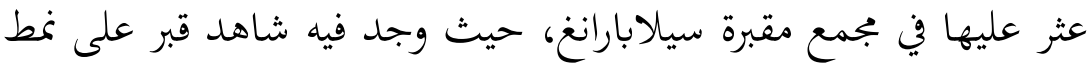

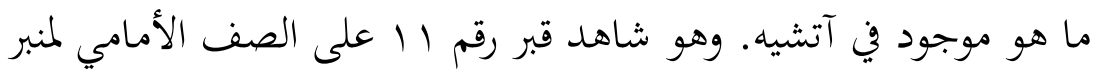

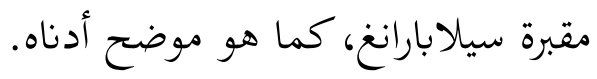
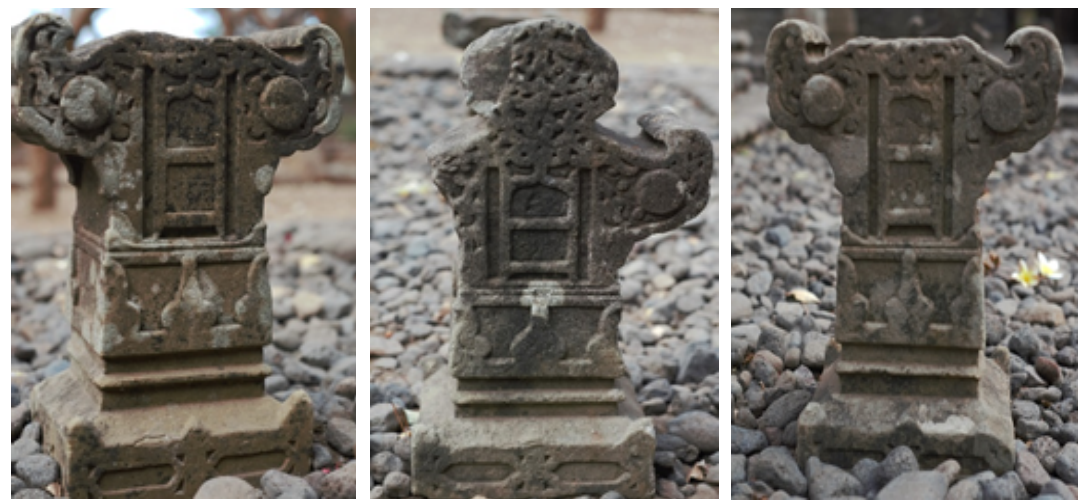

صورة شاهد قبر رقم 11 في مقبرة سيلابارانغ

(Jamaluddin 2019, 148-49)

ويتكون شاهد القبر من قطعتين، واحدة في الرأس والأخرى في القدمين،

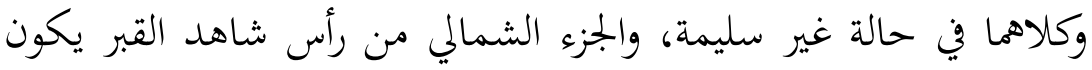

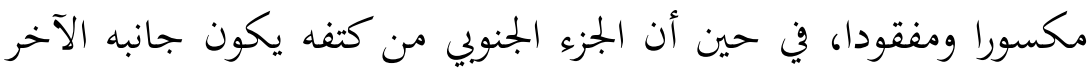

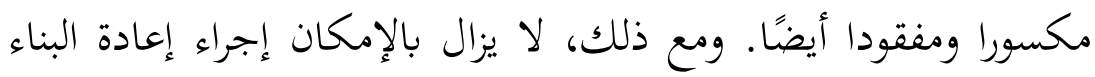

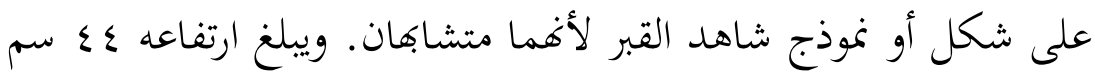

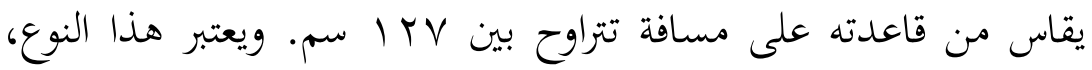

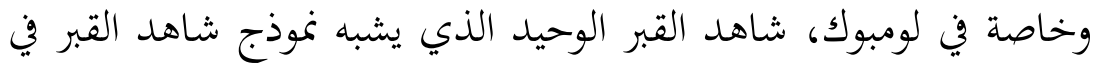
آتشيه (Jamaluddin 2019). ولتلأكد من صحة شواهد القبور الموجودة في آتشيه، كما سبق ذكره،

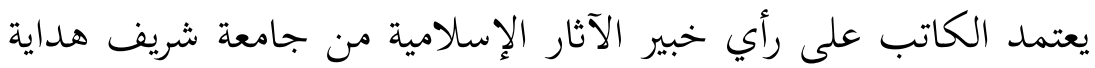

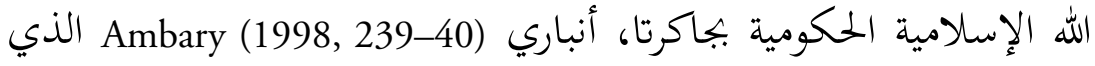


يرى أن أشكال شواهد قبور آتشيه يمكن تقسيمها إلى ثلاثة أجزاء، وهي:

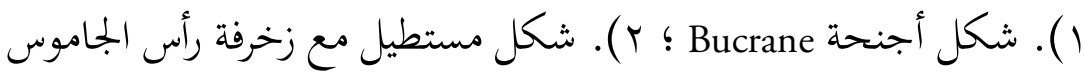
(rectangular) النوع الأول (أجنحة بوكران) من أقدم شواهد القبور أو ينتمي إلى الفئة النموذجية الأولى، وذلك من خلال جعل شاهد قبر مالك الصالح نموذجًا أوليًا، والذي بدأ من باساي كمركز لأول مملكة إسالامية في إندونيسيا، تم انتشر إلى مناطق مختلفة في نوسانتارا. وقد انتشر النموذج الأول إلى نوسانتارا في الفترة من القرن السادس عشر إلى القرن السابع عشر، ثم تبعه تصنيف شواهد قبور آتشيه المستطيلة والأسطوانية في القرن السابع عشر إلى القرن التاسع عشر. ومن خلال ملاحظة خصائص شواهد قبور آتشيه الموجودة في مجمّع مقبرة ملوك سيلابارانغ، يمكن تصنيفها أها ضمن نماذج أجنحة بوكران.

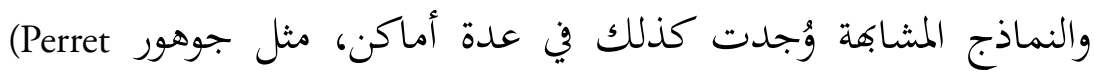
(and Razak 1999) وبينتان، وجاوا، حيث توجد أوجه التشابه فيما بينها. وتندرج نماذج القبور هذه ضمن فئة شواهد القبور في آتشيه في القرنين الخامس عشر والسادس عشر (Yatim 1987). ويرى أمباري Ambary $(1998,352$ أن شواهد قبور أتشيه المصنوعة باستخدام أحجار من نوع Meurassa (مادة لصناعة أحجار أتشيه متوفرة على طول طريق باندا أتشه إلى الساحل) تم العثور عليها في أماكن كثيرة في نوسانتارا، وماليزيا، ومناطق أخرى. وليس من المستحيل أن شواهد قبور أتشيه كانت ضمن السلع التي تم تصديرها، وذلك بسبب العلاقات التجارية والثقافية. وإذا لاحظنا شواهد قبور أتشيه الموجودة في بجمّع مقبرة ملوك سيالابارانغ تبين لنا أن المواد التي صنعت منها تختلف عن شواهد

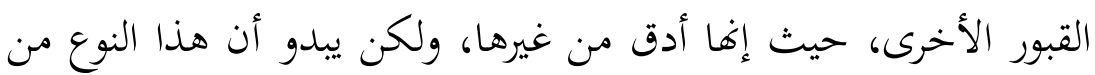


الحجارة يكسر بسهولة. وكما سبق ذكره أن كلا منهما تعرض لأضرار، لذلك قد تكون شواهد قبور آتشيه أوتي بها من منطقة المنشأ.

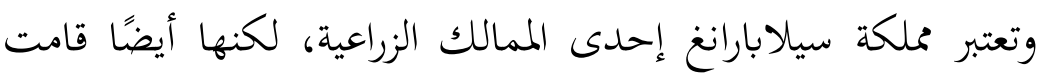

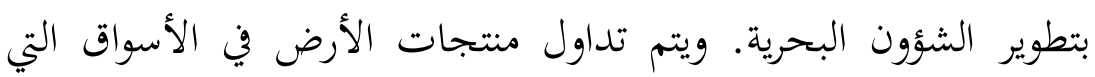

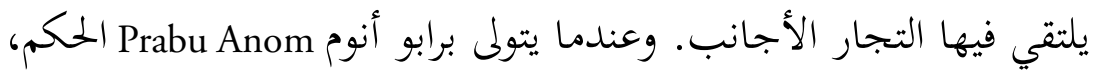

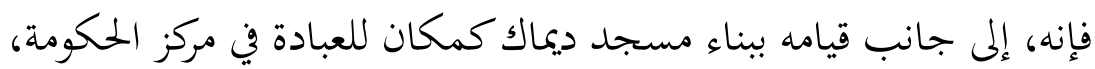

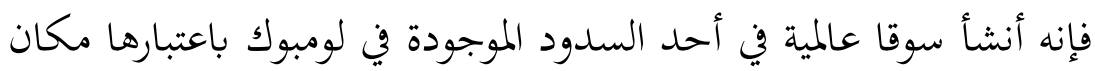

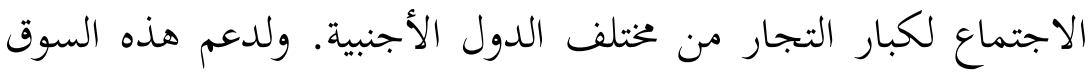

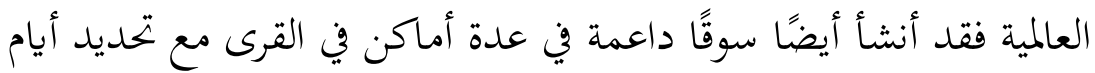
السوق، وذلك تحت تنسيق رئيس المقاطعة (Demung) مثل سوق أيكميل Aikmel

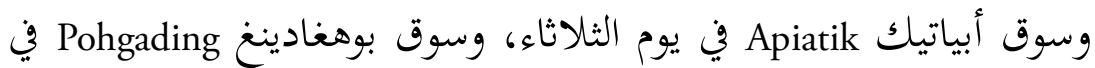
يوم الخميس، وسوق ماسباغيك Masbagik في يوم الاثنين. بينما سوق

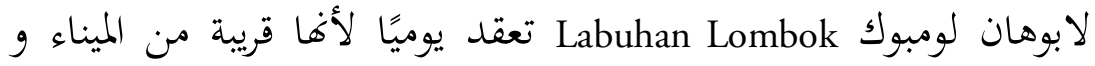

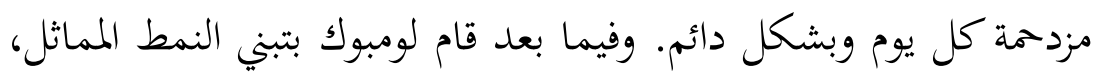

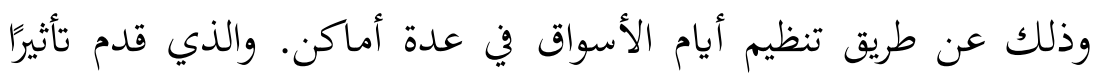

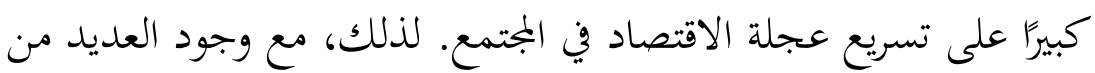

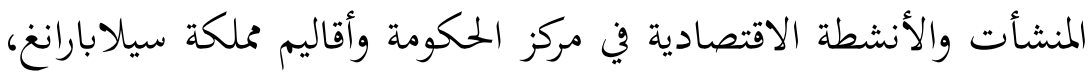

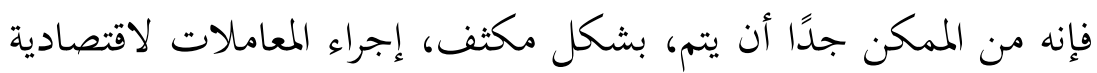

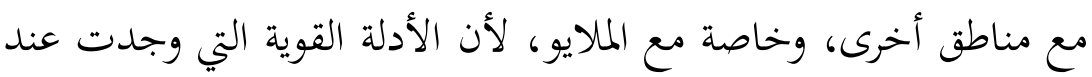

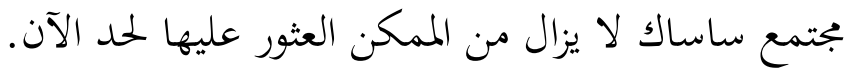

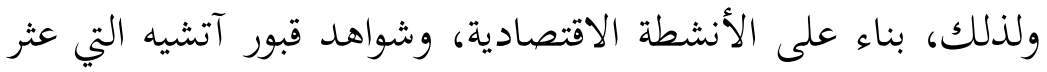

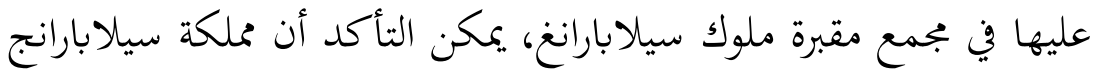

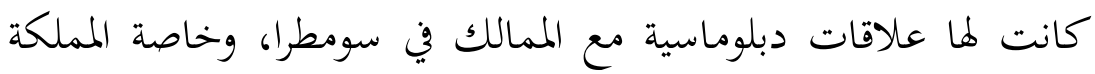


الواقعة في الطرف الشمالي لجزيرة سومطرا. وعن طريق ملاحظة انتشار

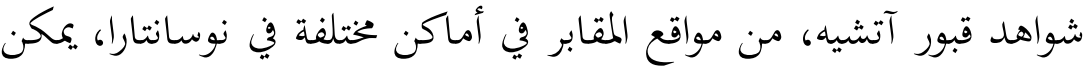

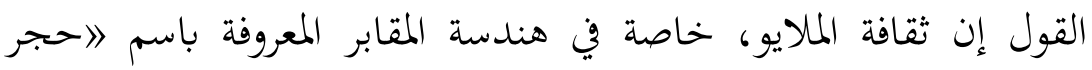

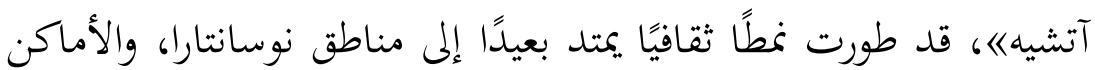

$$
\text { المسلمة الأخرى في جنوب شرقي آسيا. }
$$

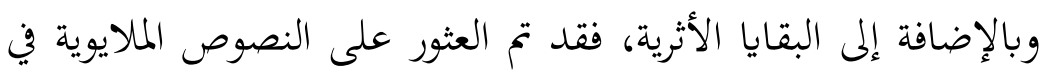

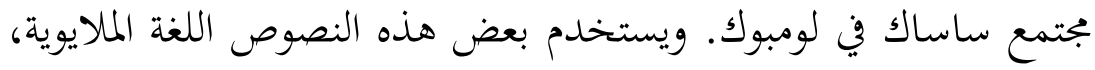

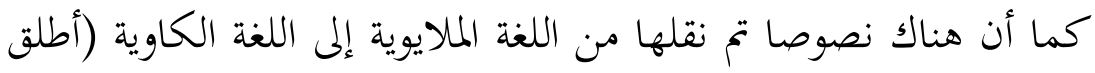

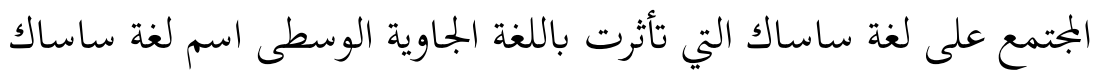

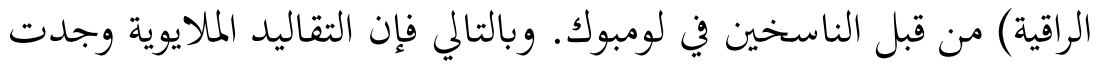

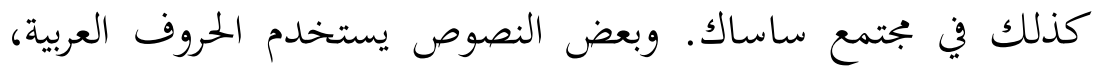

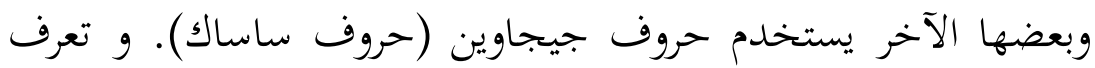
تقاليد قراءة قصص الملايو في ساسك باسم Bakayat. والنصوص المالايوية

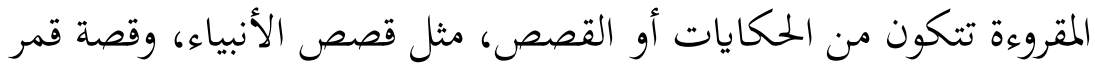
الزمان، وقصة Nabi Bercukur (النبي يحلق شعره)، وقصة Ali Hanafiyah

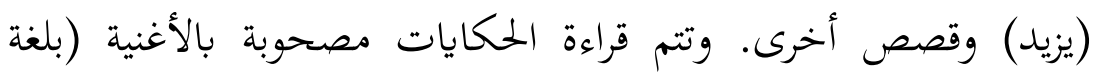

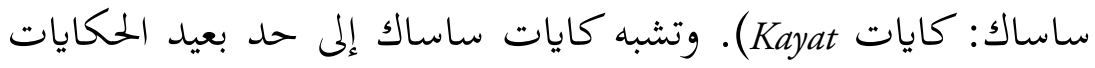
المتداولة في الملايو. كما تتطلب هذه المات القراءة أيضًا المترجمين والمساعدين الماتين.

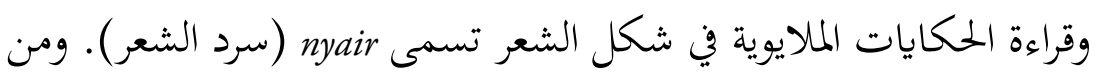

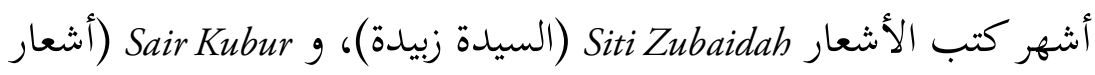
القبور)، و Q Q Q (قمر الزمان) (Herman et al. 1990, 11). وتعد تقاليد قراءة النصوص التي تتكون من بيباوسان Pepaosan، وبكان وانيكايات

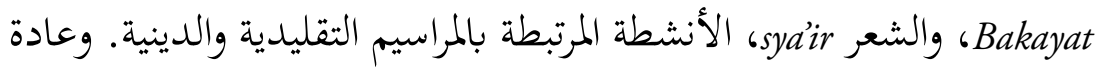

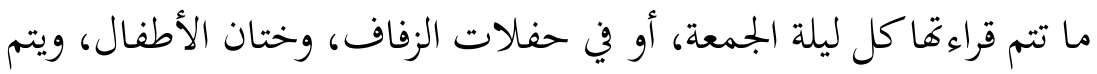


ذلك غالبا في المساء (Jamaluddin 2011b, 82). ولا تزال التقاليد المتعلقة بالمخطوطات تعتبر من التقاليد المهمة لدى ججتمع ساساك، ليس فقط في القرى ولكن أيضا في المدن حيث لا يزالون يحافظون عليها. وفي العصر المبكر للمملكة الإسلامية، كانت المخطوطات المتداولة عند بجتمع ساساك، بشكل عام، لا يُعرف مؤلفها وخاصة في النسخ المنقولة. والحروف المستخدمة في مخطوط ساساك هي حروف جيجاوين، والحروف العربية، والحروف البالية، والحروف البوغيسية (هذه الأخيرة نادرة العثور عليها)، وكذلك بالنسبة للغات المستخدمة، فهناك ستة لغات، على الأقل، وهي اللغات السنسكريتية، والجاوية، والساسكية، والبالية، والعربية، والملايوية. وفيما يخص الحروف فوإِ إن أكثرها استخداما هي الحروف الساساكية والعربية، أما من حيث اللغة فإن اللغات الساساكية والجاوية والعربية والملايوية هي اللغات الأكثر استخداما، وأما المخطوطات الملايوية التي تم نسخ حروفها ولغاتما فإفا تستخدم حروف جيجاوين واللغة الساسكية الراقية (الساساكية الجاوية الوسطى)، إضافة إلى استخدام بعضها اللغة العربية الملايوية.

إنشاء شبكة علماء لومبوك وملايو من القرن السابع عشر إلى القرن العشرين لقد ساهم تدفق الملاحة البحرية من مدن لومبوك إلى الشرق الأوسط عبر سنغافورا، في ذهاب مجتمع ساساك إلى مكة المكرمة. وكان سكان لومبوك يفضلون استخدام خدمات الشحن التي تقدمها الحلكومة البريطانية

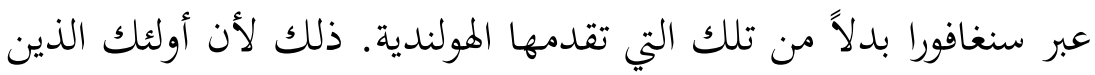
يذهبون عن طريق سنغافورا، لا يطالَبون بتوفير كثير من الشروط والمتطلبات الإدارية، بما فيها جواز السفر، حيث يسمح للمسلمين بالسفر إلى الشرق 
الأوسط بدونه (Steenbrink 1984, 101) سواء كانت أهدافهم لأداء مناسك الحج أو من أجل طلب العلم. كانت مشاركة أبناء ساساك في الخطاب الفكري العالمي في الحرمين

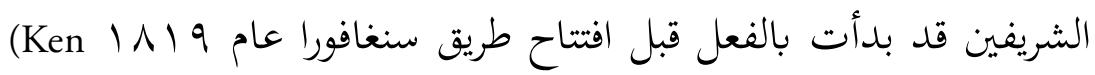
(c1978, 56) ويُعتقد أفا في القرن الثامن عشر الميلادي. وذلك اعتمادا على عدة مصادر تفيد أن هناك بعض العلماء من أصول لومبوك أصبحوا معلمين في المسجد الحرام، كما أصبحوا توان غورو Tuan Guru (المشايخ) في مجتمع ساسك في القرن الثامن عشر، وهم من خريجي

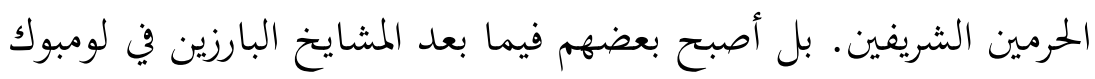

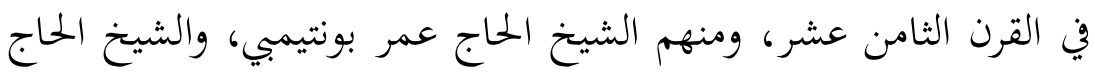

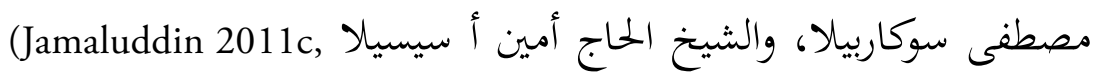
(233. وكان هؤلاء المشايخ قد أدوا فريضة الحج في منتصف القرن الثامن عشر الميادي، وعاشوا لفترة في مكة ويتعلمون من كبار العلماء في المسجد الحرام. ولكن لم يتم العثور على مصادر تذكر بالتفصيل أسماء

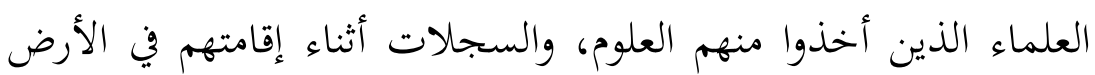

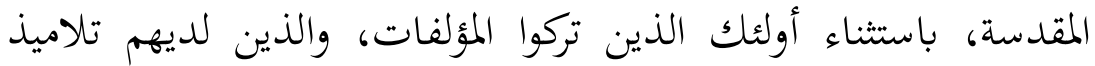
يقومون بالدعوة الإسلامية في الجمتمع، بحيث يمكن تتبع سيرهم الذاتية عبر تلاميذهم أو عائلاكم. و إذا نظرنا إلى أدوارهم أثناء إقامتهم بمكة تيكة

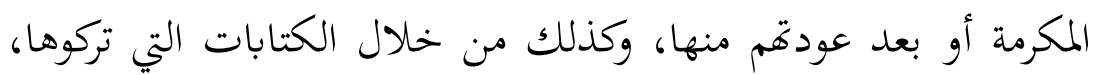
يمكن القول بأفم ناقلون رئيسيون للتقاليد العلمية في الشرق الأوسط في جتمع ساساك بلومبوك (Jamaluddin 2011c, 235). ومن خريجي الحرمين الشريفين المنحدرين من لومبوك من هم أصبحوا توان غورو الذين نجحوا فيما بعد ليصبحوا علماء كبار، وأشخاصا ذوي نفوذ في المجتمع، وهم طلاب توان غورو (المشايخ) أو ينتمون إلى شبكتهم الفكرية. 
وقد وضع الجيل الأول من هؤلاء المشايخ أساسا يعتمدون عليه في إنجاح

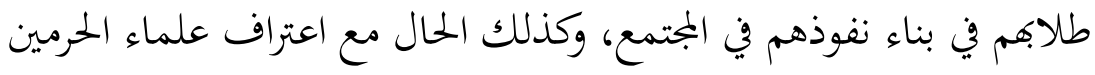

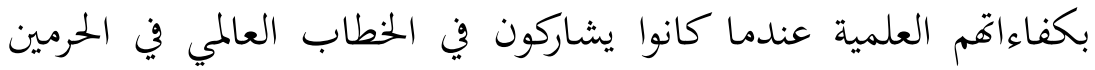

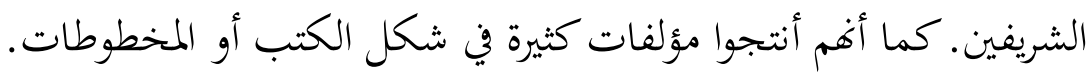

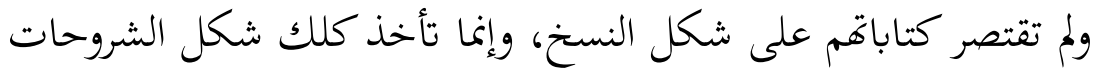

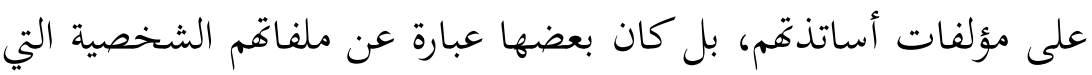

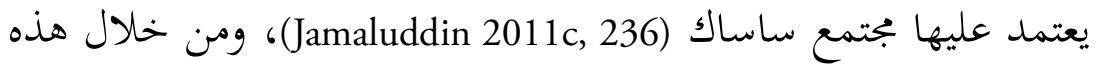
المخطوطات يمكن الوقوف على وجود العلاقة بين علماء لومبوك وعلماء

$$
\text { ملايو - سومطرة. }
$$

وكانت لمشايخ لومبوك علاقة مع علماء سومطرا في ظل شبكة العلماء.

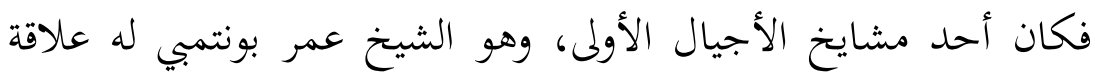

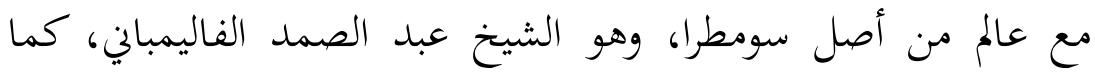
ذكر ذلك في غخطوطات تم العثور عليها في لومبوك، وتحديدا في غخطوط

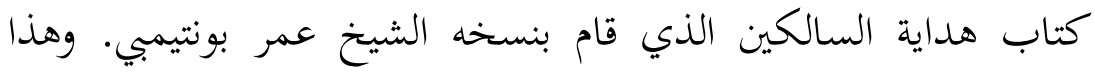

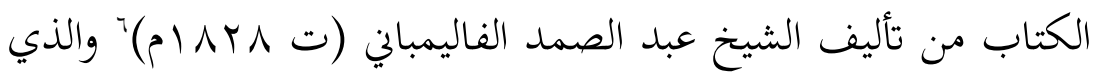

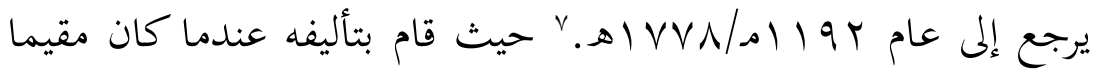

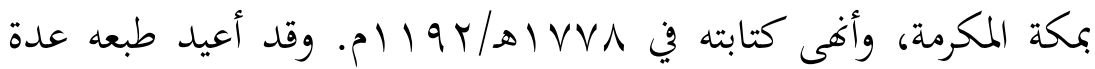

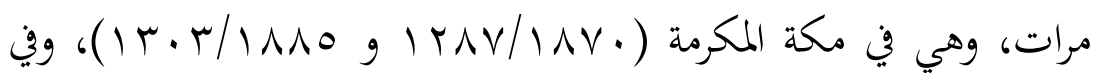

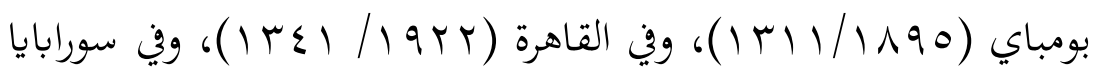

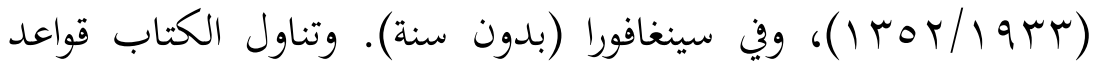

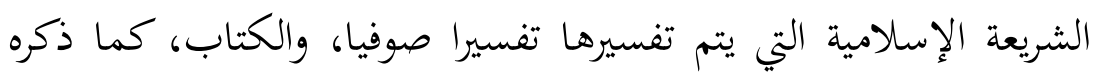

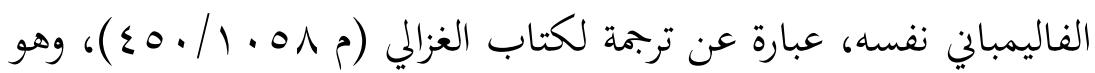

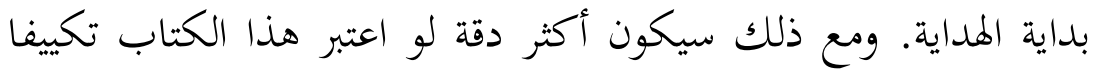

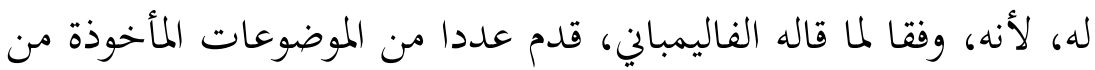




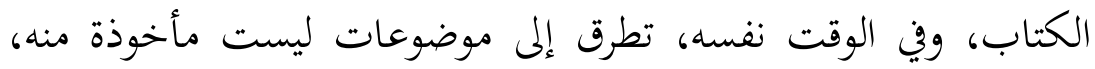

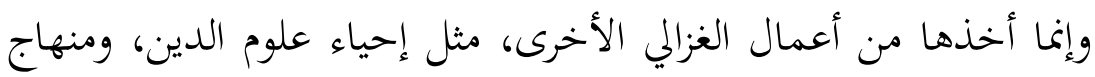
العابدين، والأربعين في أصول الدين (Azra 2005, 342).

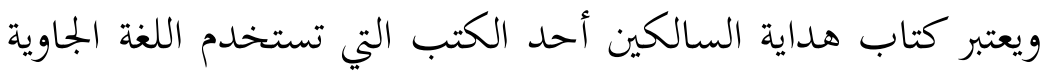

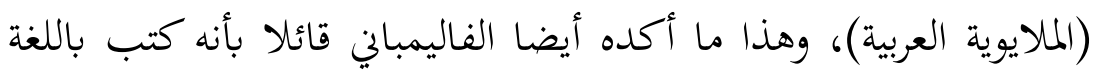

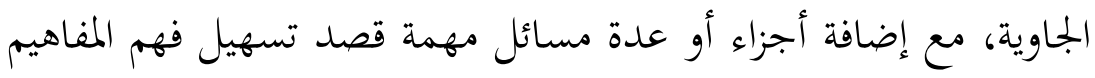

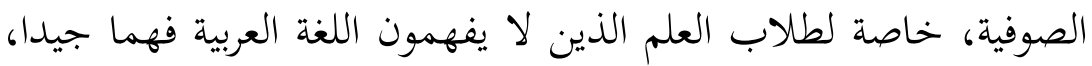

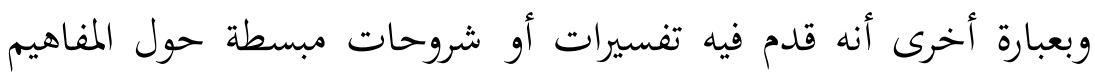

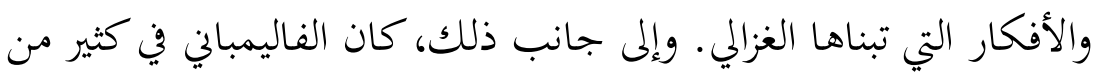

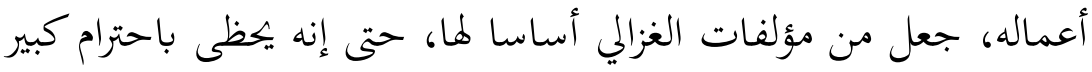

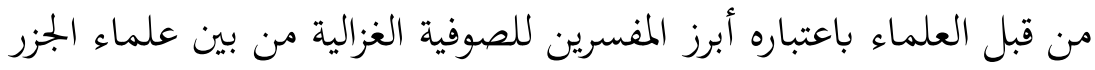
الملايوية (Abdullah 2015, 100). و ذكر أزرا Azra (2005) أن الفاليمباني كان الأبرز من بين العلماء

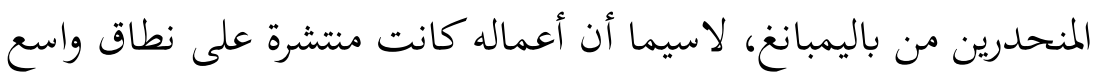

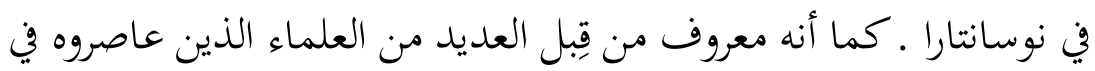

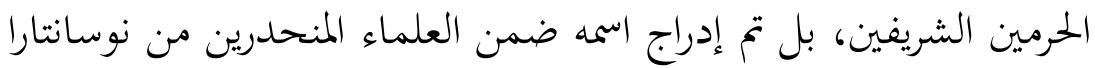

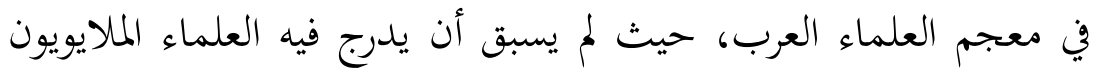

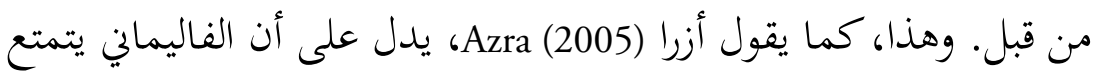

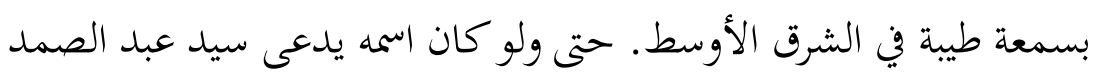

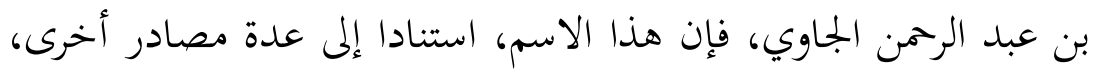

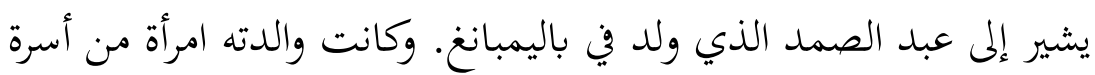

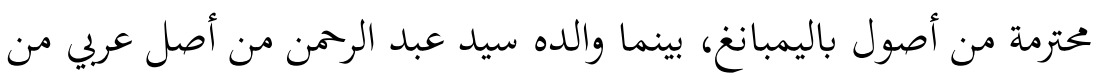

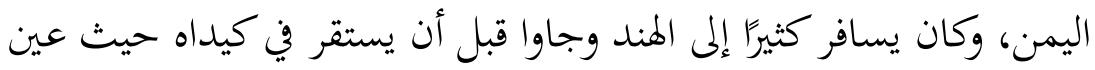
مفتيا في سلطنة كيداه. 
ومن خلال هذا الكتاب المكتوب باللغة الجاوية، تم الوقوف على العلاقة

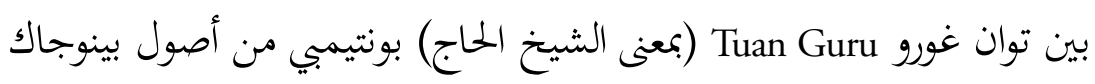

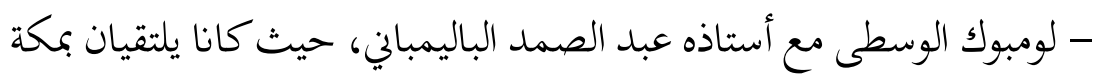
المكرمة، وبالتالي فإن التفاعل بينهما لم يحدث في نوسان المبانتارا، وإنما في الحرمين

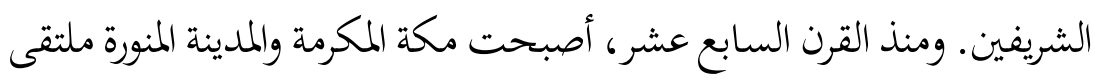
للعلماء الذين جاءوا من مختلف أنحاء العالم الإسلامي، وذلك بعد استعادة

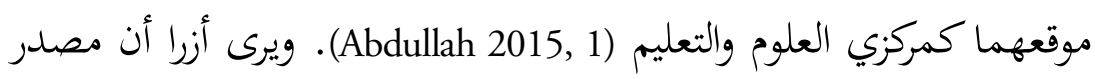
ديناميات الإسلام في القرن السابع عشر إلى القرن الثامن عشر هو شبكة العلماء التي اتخذت من مكة المكرمة والمدينة المنورة مقرين لما، وذلك نظرا لمكانتهما

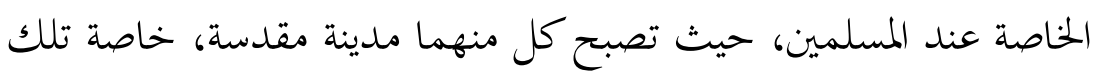

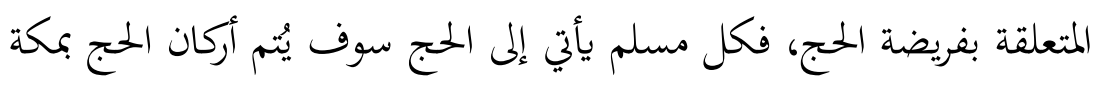
المكرمة، ويكمله بزيارة قبر النبي عليه الصلاة والسلام، ويصلي أربعين صلاة في المدينة المنورة. وهذا ماكان يدفع عددًا كبيرًا من المسلمين في العالم إلى زيارة هاتين المدينتين المقدستين والإقامة فيهما، الأمر الذي أدى في فهاية المطاف إلى إنشاء نوع من الشبكة العلمية، والخطاب العلمي الخاص (Azra 2005).

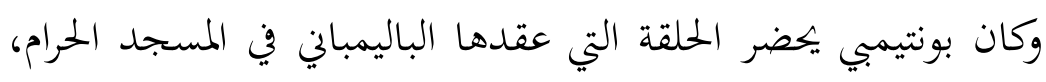
وهذا التفاعل الذي حصل في مكة المكرمة أدى إلى نشأة العلاقات العلمية

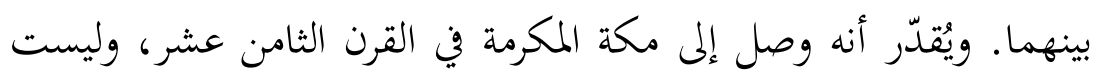
هناك سجلات تؤكد ميلاد هذا الشيخ الذي جاء من برايا، ومع ذلك، ولك، استنادا إلى تاريخ ميلاد تلميذه المدعو الشيخ الحاج عبد الغفار الذي ولد هلدياء

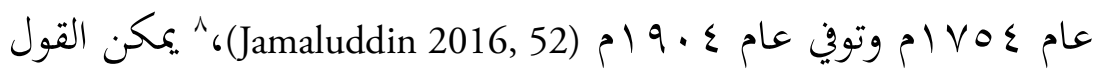
بأن الشيخ الحاج عمر بونتيمبي أكبر منه سنا.

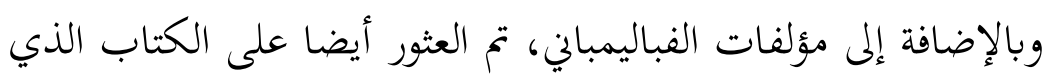

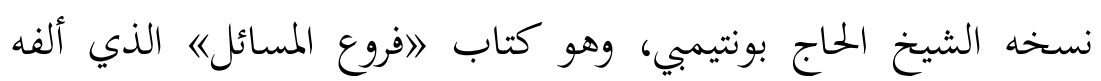


أحد علماء الملايو الإندونيسيين في القرن الثامن عشر، وهو الشيخ داود

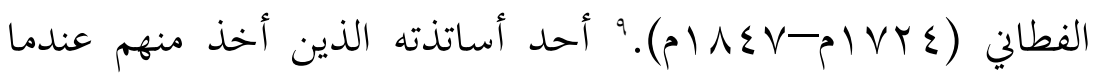
كان بمكة المكرمة. ويعتبر الفطاني عالما ناجحا في التوفيق بين الجوانب

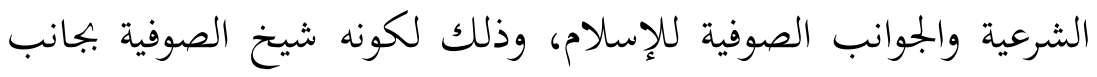
كونه فقيها، ومن مؤلفاته التي تمثل ذلك كتاب لاهداية المتعلم وعمدة المعلمه الذي يبحث في المسائل الفقهية بصفة عامة، وكتاب 》هنية المصليه الذي تحدث عن الصالاة، وكتاب اهتج الراغبين في سبيل المتقين《) الذي تناول العقود التجارية، وكتاب لاغاية التقريب)الذي يبحث في المواريث

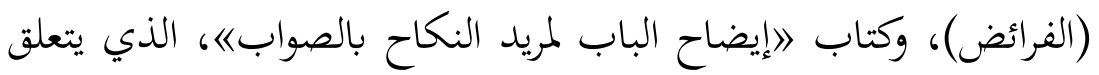
بالزواج والطالاق، وغيرها من المؤلفات الفقهية في شكل الرسائل القصيرة .(Abdullah 1990, 99-100; Azra 2005, 340; Jamaluddin 2011c, 252) أما كتاب 》افروع المسائل) فإنه يحتوي على القواعد والتوجيهات المتعلقة بالحياة اليومية، وهو عبارة عن تكييف لكتاب 》الفتاوى《) الذي ألفه الشيخ شمس الدين الرملي، وكتاب لاكشف اللثامهي لحسين بن محمد المحلي، الذي تم تأليفه في شكل السؤال والجواب. ويرى أزرا أن هذا النوع من أسلوب الكتابة، هو طريقة جديدة يستخدمها الفطاني في شرح المسائل الفقهية عن فئن

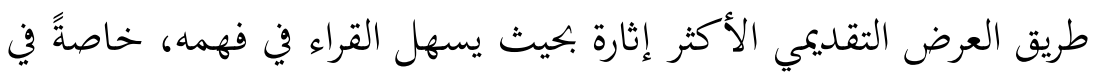

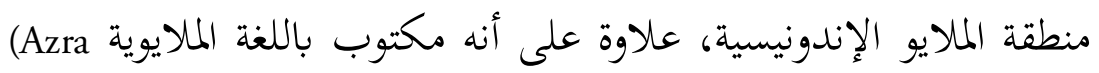
(2005, 341، ومن خلال هذا الكتاب يمكن القول بأن الشيخ بونتيمبي له علاقة أيضا مع هذا العالم الفطاني، بل إنه قدم شروحات أكثر تفصيلا للمسائل الواردة فيه. وله كتاب آخر حول الفقه، غير أن هذا الكتاب، لسوء الحظ، عثر في

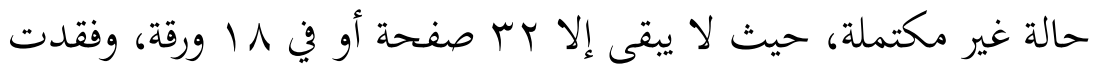
كثير من أجزائه، وكذلك الغلاف الخارجي، والصفحات الأولى لم تعد 
موجودة، كما فقدت منه العديد من أجزاء الأبواب والفصول إلا المباحث

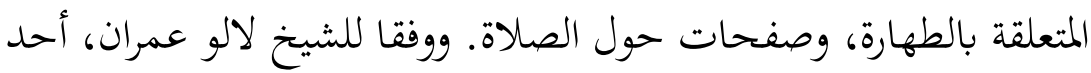

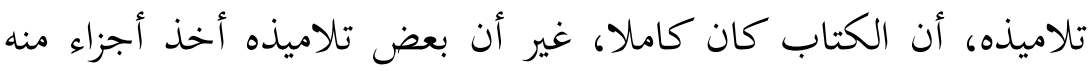

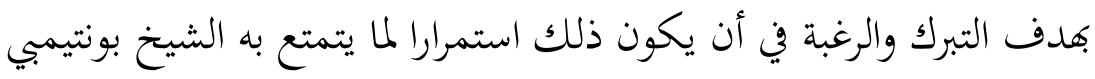
من العلوم. وقد تأثر الشيخ بونتيمبي أثناء إقامته بمكة المكرمة بهذين الشخصين،

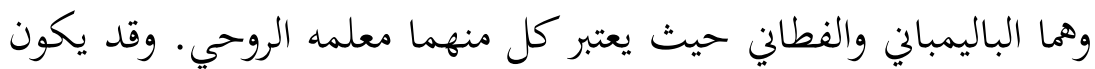

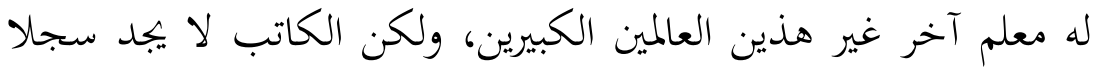

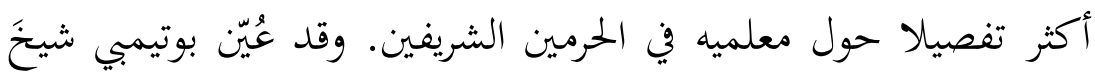

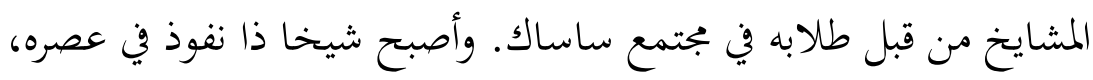

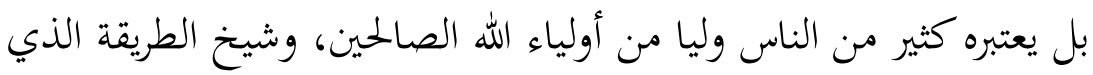

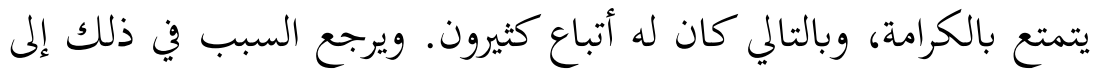

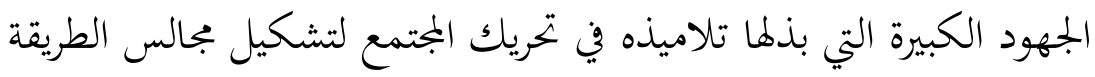

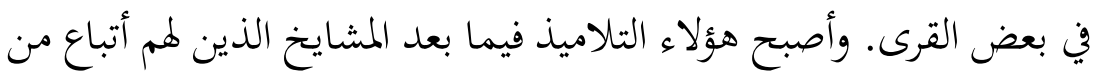

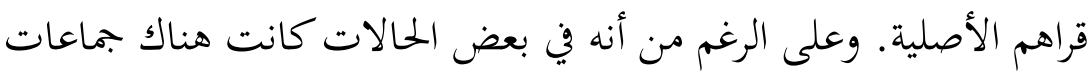

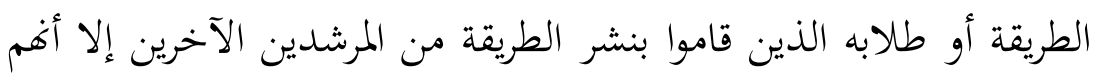

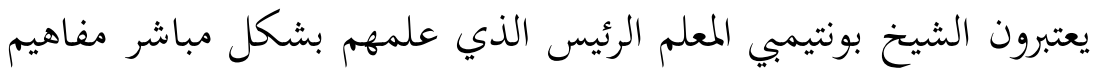
الطريقة منذ البداية.

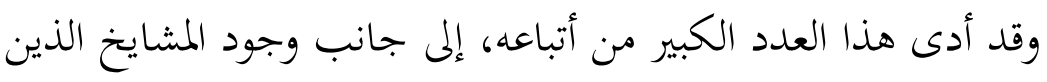

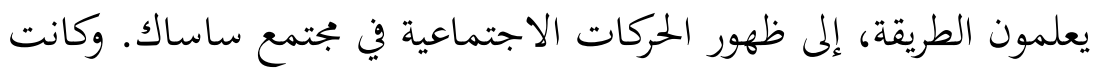

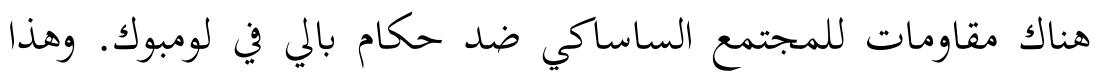

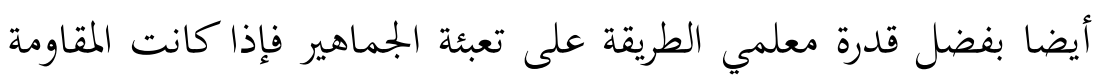

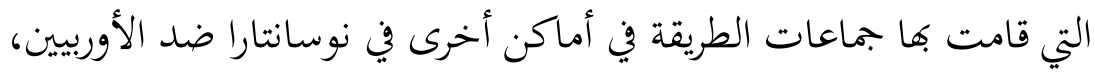

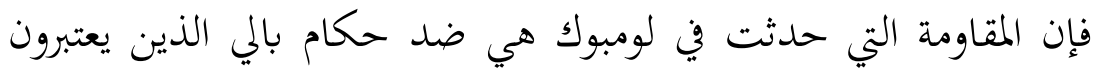


أهم يتصرفون بشكل تعسفي بحاه مسلمي لومبوك. كما قاومت جماعات

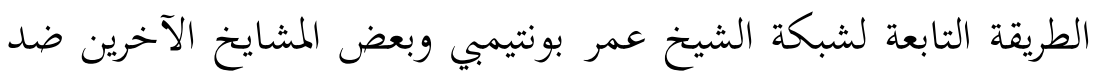

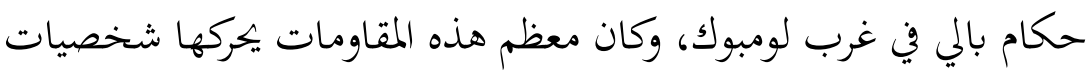
بارزات من جماعات الطريقة. ومن تلاميذه الذين أصبحوا معلمين مؤثرين الشيخ الحاج عبد الغفور، والشيخ الحاج لوبان، والشيخ الحاج صديق، والشيخ الحاج فيصل برايا. وكان الشيخ الحاج عبد الغفور، إلى جانب أنه تعلم الطريقة من العلماء

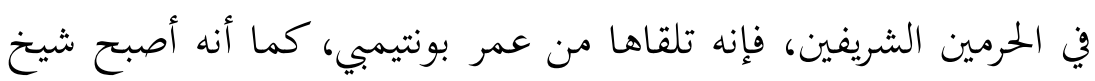
الطريقة المؤثر في مجتمع ساساك، بل أكثر من ذلك أنه كان يحظي باحترام كبير من قبل الملك أناك أغونغ الذي اتخد من تشاكرا Cakra مقرا له. وذكر بعص المصادر أنه، بناء على توصية من سيد عبد الله (من أصل عربي)،

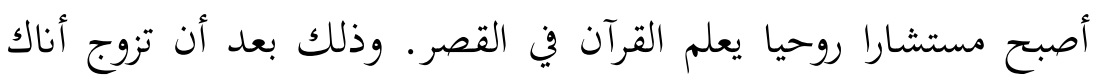
أغونغ من ديندي أمينة إحدى نبيالت ساساك من أصل كاليجاغا لومبوك

الشرقية (Jamaluddin 2016).

وهناك بعض المؤلفات التي كتبها الشيخ الحاج عبد الغفور والتي يتوقع

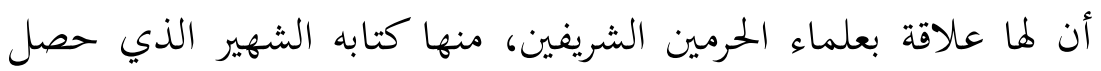
عليه الباحث بعنوان لاكتاب المعراج)،، 'ا وهو كتاب مؤثر للغاية في جمتمع ساساك، حيث يجب قراءته في مناسبة الاحتفال بالإسراء والمعراج باستخدام الألحان التي يعرف عند بجتمع ساساك ب يشارك فيها عادة ما لايقل عن · ا أشخاص، ابتداء من الساعة التاسعة

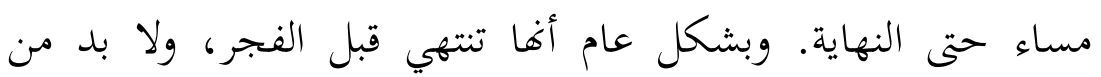

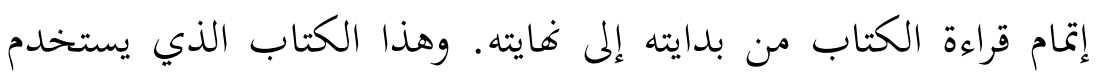
اللغة الملايوية يهكي قصة الإسراء والمعراج التي قام بها النبي عليه الصالاة والسلام. وهناك شخص يقرأ القصة وشخص آخر يترجمها إلى اللغة 
الساساكية. وبالنسبة للقارئ فإنه يعتمد على ما هو مكتوب في النسخة

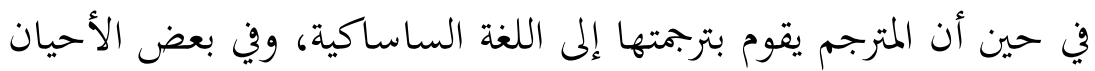
يقدم شروحات وتوضيحات أكثر تفصيلا. ويرى الكاتب أنه من المرجح أن الكتاب له عله علاقة بالكتاب الذاب الذي ألفه عالم

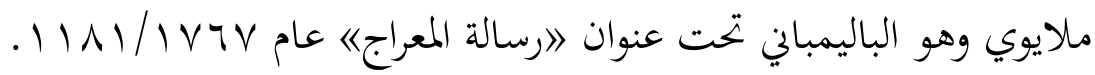

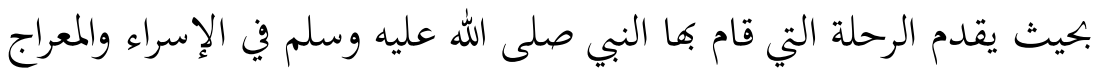

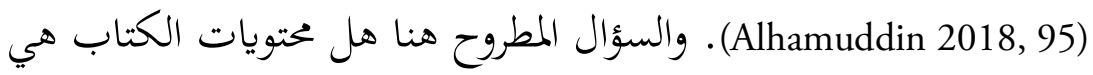
نفسها، والأمر بطبيعة الحال بحاجة إلى الدراسة وإجراء المقارنة بينهما. ولكن إذا نظرنا إلى العنوان، فمن الممكن أن تكون بينهما أمور مشتركة.

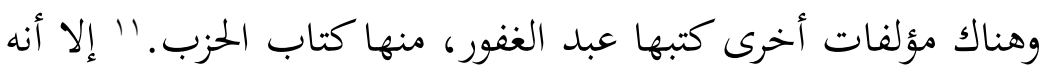

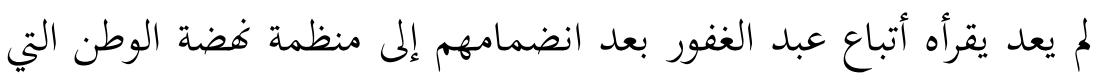

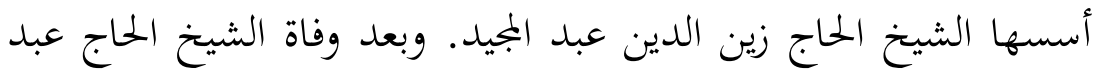

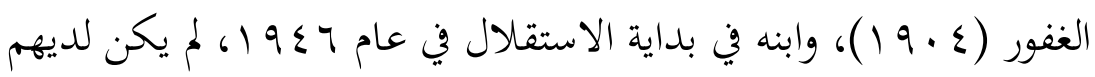
شخصية مركزية، حتى إن بعض أحفاده لم يعودوا قادرين على أن أن يكونوا

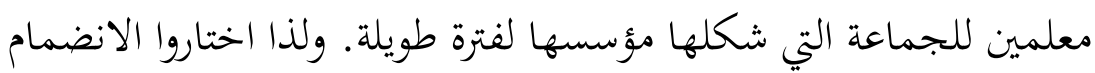

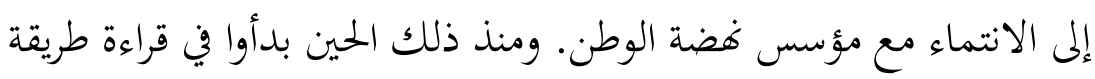

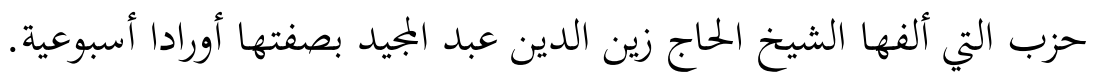

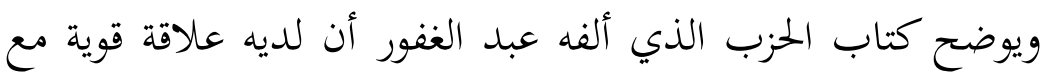

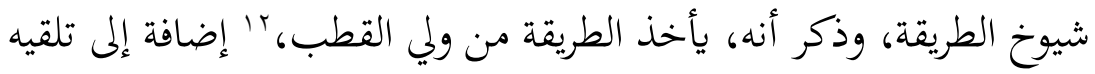
من بونتيمبي.

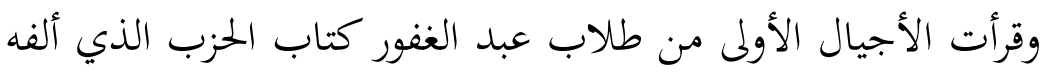

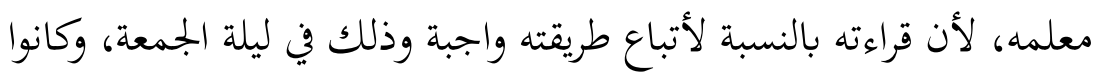

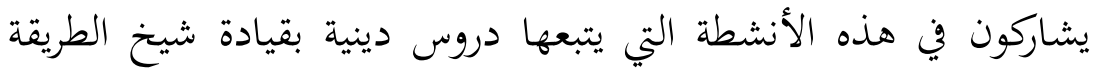

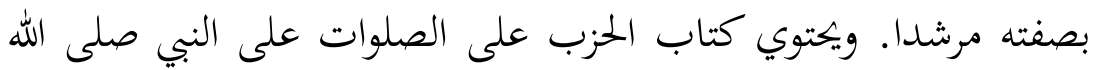


عليه وسلم والأدعية والراتب أو القصائد المقتبسة من العلماء السابقين، ومنها قصيدة البردة للإمام البصيري (Jamaluddin 2016, 58). وإلى جانب عمر بونتيمبي، فإن عمر كيلايو له علاقة أيضا بالعلماء في

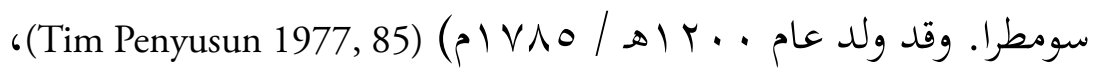
وسافر إلى مكة المكرمة حوالي عام الو9V وهو في ع ا من عمره. وعاد إلى

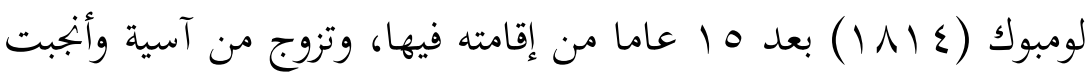
أولادا، منهم محمد جنيدي (ابنه الأول، ولذلك يكنى بأبي جنيد أو توان غورو جنيد)، غير أنه مات في سن مبكرة، وبعد سنوات قليلة، عاد عمر إلى مكة مع زوجته ووالدته اللتيين توفيتا فيها. ثم تزوج مرة أخرى من امرأة مصرية أنجبت له بنتا وولدين (Ja) (Jamaluddin 2011c, 270).

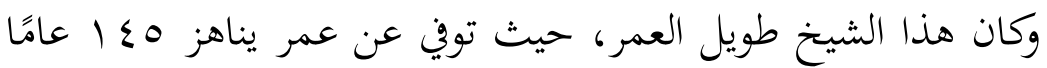

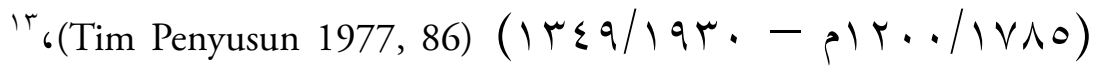
لذا، فإنه التقى بثلاثة أجيال تحته على الأقل. وعندما كان في مكة أقام نوعا من حلقات العلم في المسجد الحرام (Azhar and Tsalis 2003, 19). وهذه الحلقات جعلته عالما مشهورا على مستوى العالم، بمعنى أن الذين يتعلمون

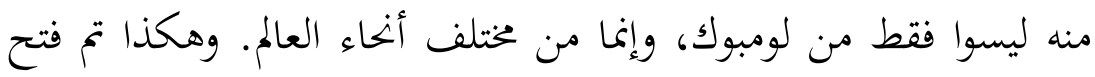
شبكة العلماء على نطاق أوسع. وبالإضافة إلى حلقاته في المسجد الحرام فإنه كان يعطي الدروس في منزله ( Jamaluddin 2011c, 272 ). وكان طلابه يأتون من مختلف البلدان والمناطق، مثل باليمبانغ، وجوهور، وبينانغ، كيده، وجاوا، وبالي، وبيراك، ولامبونغ، ولومبوك. وأصبح طلابه

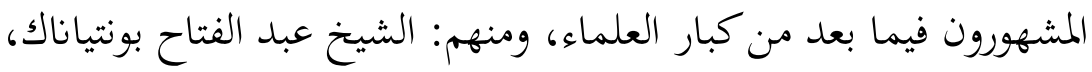
والشيخ داود باليمبانغ، والشيخ نواوي، والشيخ عبد الرحيم كيداه، والشيخ

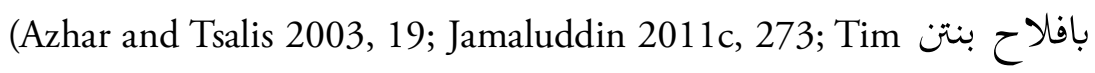
(Penyusun 1977, 86) ومن أصدقائهم في الدارسة الشيخ السيد اليماني، بنئ. 
والشيخ عمر باجنت الحضرمي، والشيخ عبد القادر المندلي، والشيخ مختار

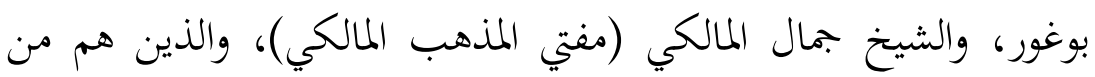

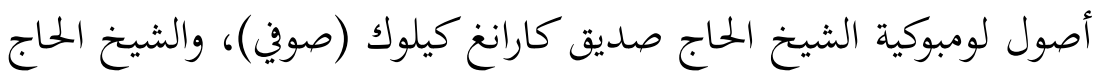

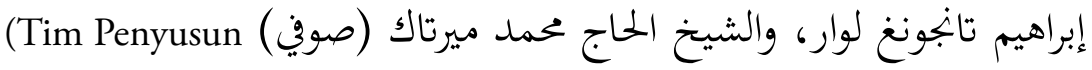

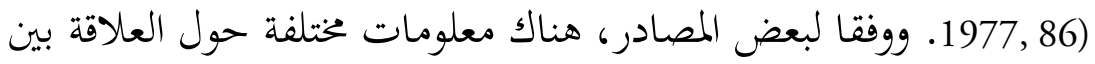

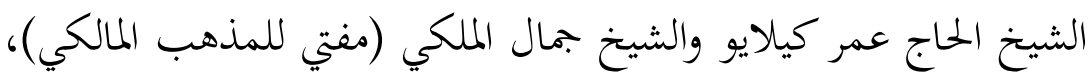

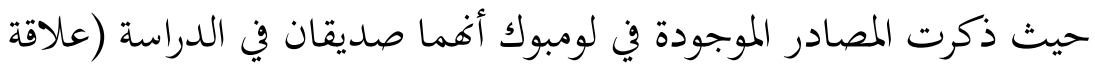

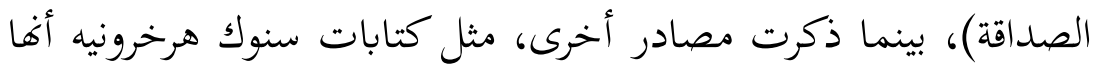

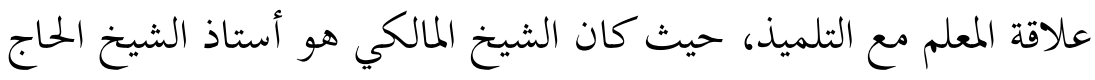

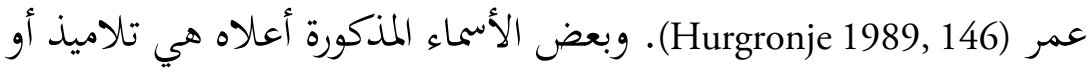

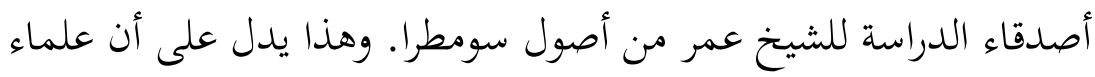

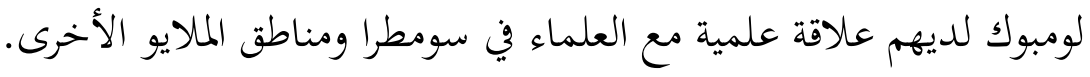

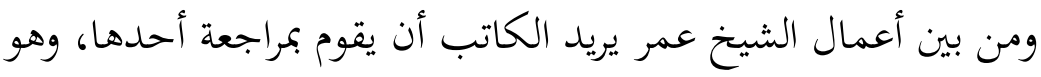

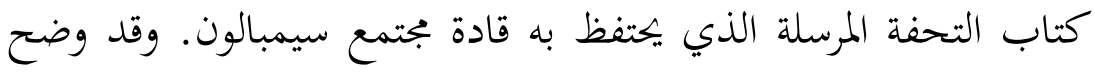

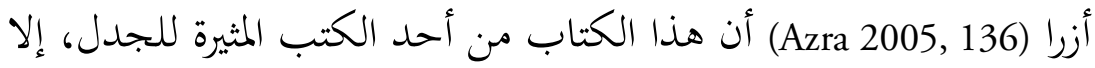

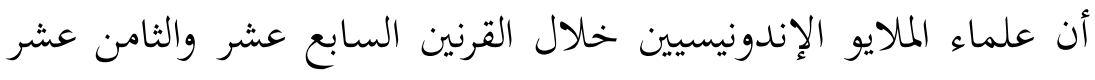

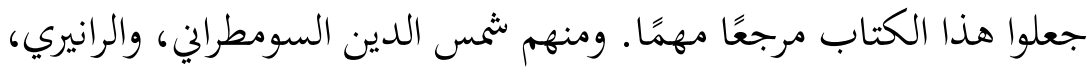

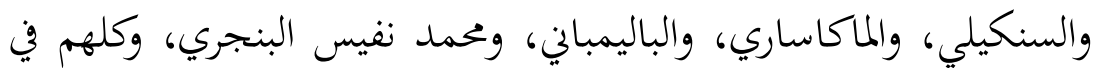

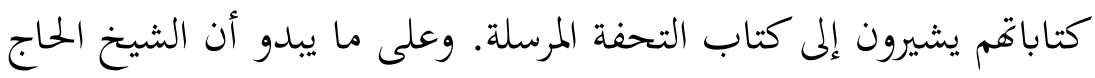

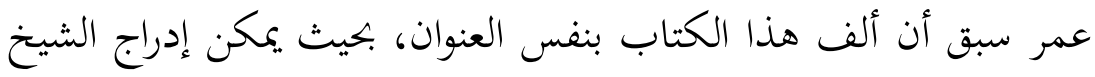

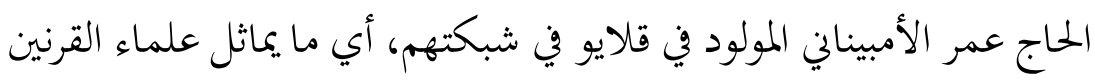

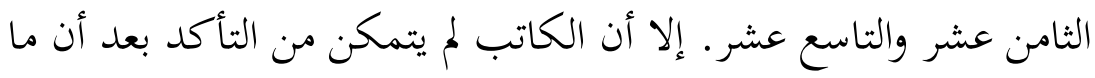

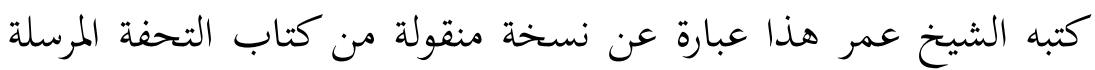

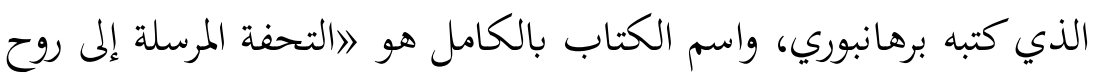


النبيه الذي كتبه محمد بن فضيلة بوهانبوري الهندي (و ب • اهـ/ • با (م))،

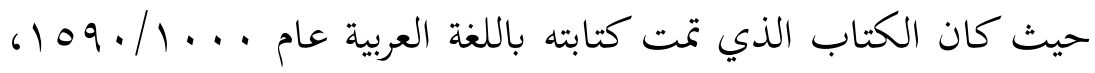
ينتشر في نوسانتارا وعلى نطاق واسع، وذلك في وقت غير بعيد عن كتابته،

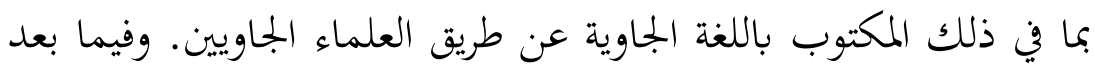
قام أنتوني جونز، أحد خبراء الجامعة الوطنية الأسترالية بدراسته وترجمته إلى دئل اللغة الإنجليزية (Azra and Fathurahman 2005, 110). ولمزيد من التوضيح حول هذا الموضوع ينبغي أن تكون هناك دراسة خاصة به.

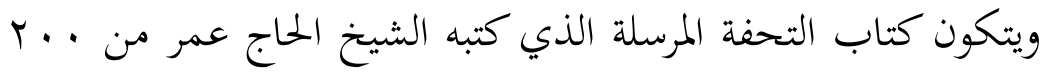

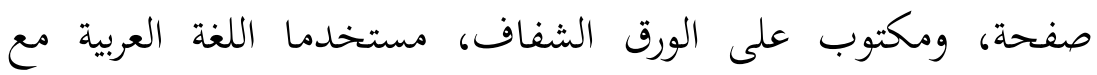

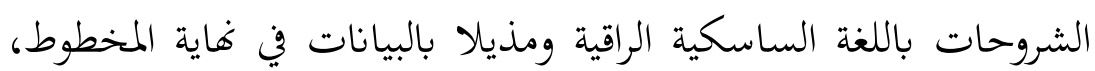
بحيث كتب فيها ما يلي: تم الكتاب المسمى بالتحفة المرسلة بعون الله الملك الوهاب، والله أعلم. تمت في يوم الثلاثاء ( •0هـ).

وأما من حيث محتوياته بشكل إجمالي فيمكن وصفه أنه يستخدم طريقة السؤال والجواب. ويشرح الجزء الأول يشرح أركان الإسلام، وأركان

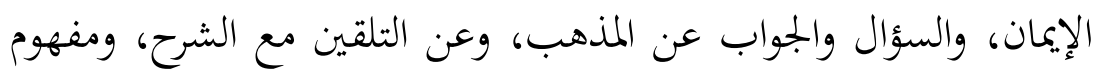

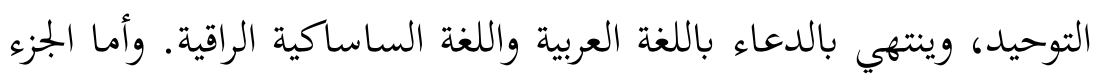
الثاني ففيه حديث عن معرفة حقيقة الخلق مبدوءا بشرح مفهوم القلم الذي خلقه الله في خمسمائة عام، ثم أمره الله بأن يكتب لفظ لفظ البسملة في خمسمائة عام أيضا...إلخ. ثخم تطرق إلى الحلديث عن خلق المخام، المخلوقات

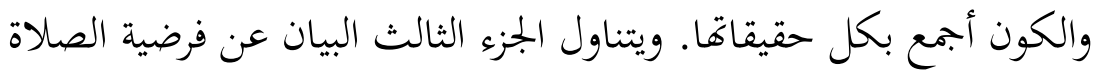
وحكم تاركها. ويبدو أن هذا القسم يؤكد أن مفهوم الشريعة وخاصة

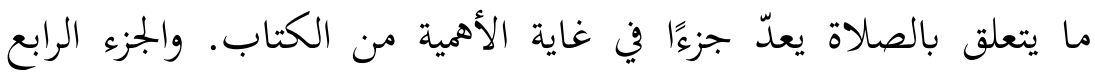
يتحدث عن الأحكام العقلية وشرح صفات الله، والجزء الخامس يبحث 
في توحيد الألوهية وتوحيد الربوبية، والقسم الذي يليه يدور حول مفهوم

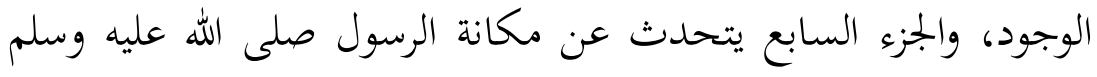
عند الله. ويصف الجزء الأخير من الكتاب العلاقة بين الله تعالى والإنسان.

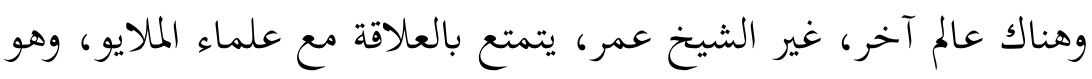

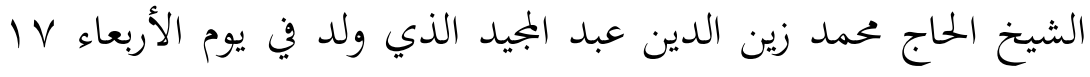

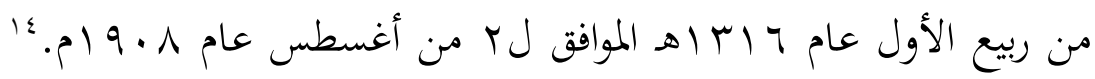

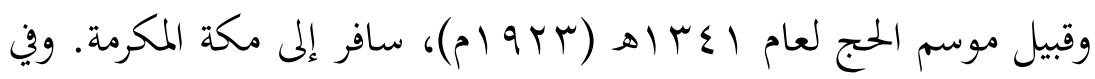

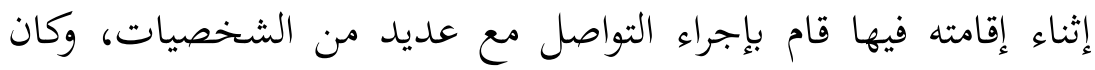

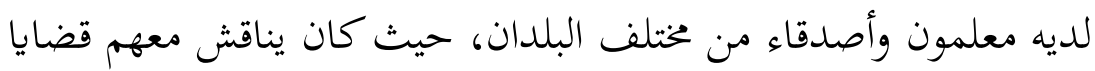

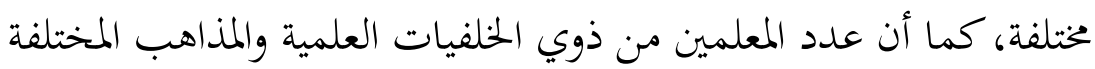
جعله عالما متعدد المواهب ولديه شبكات علمية والمعلمين واسعة.

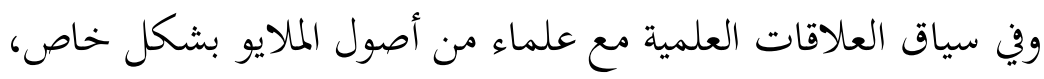

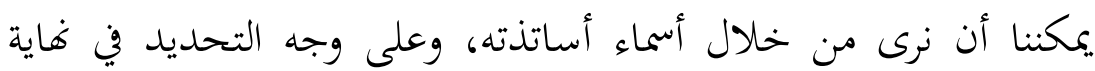

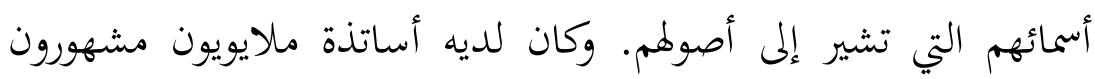

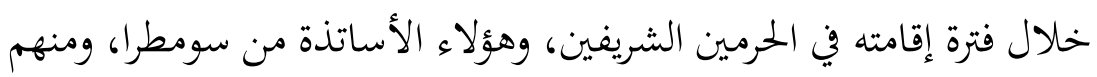
الخطاط الشيخ عبد العزيز لانغكات، والعلامة الشيخ عبد القادئ القادر المنديلي

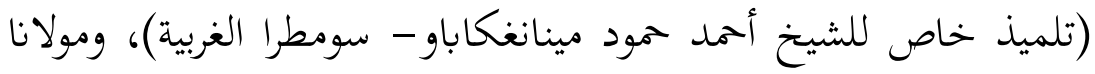

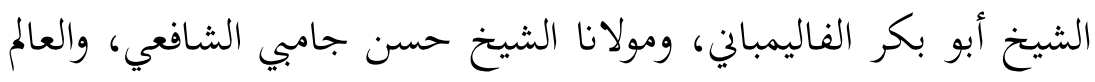

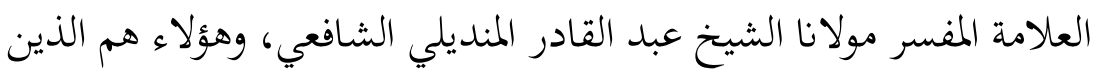

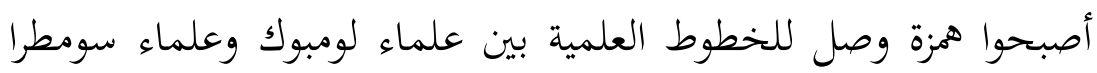

$$
\text { وغيرها من جزز الملايو. }
$$

وبعض الأسماء الأخيرة هي من علمئون علماء الملايو الذين لديهم علاقات

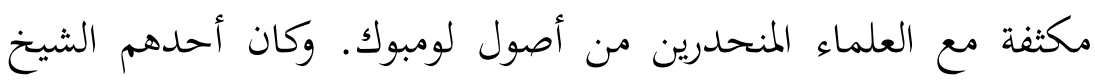

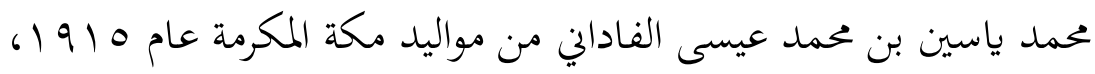


وتوفي في ·r يوليو • 199. وكان أحد أساتذته هو الشيخ الحاج زين

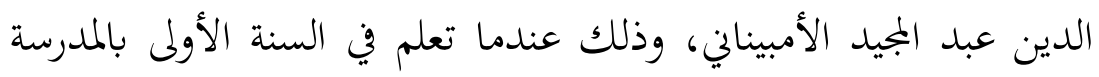

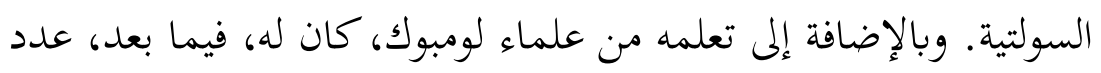

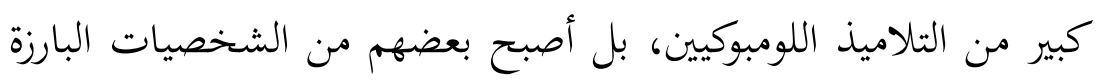

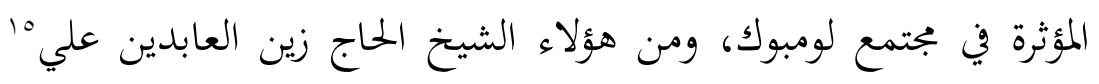

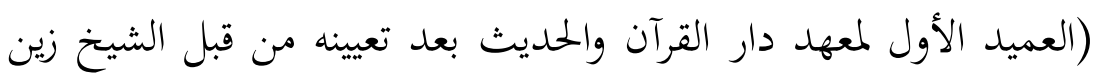

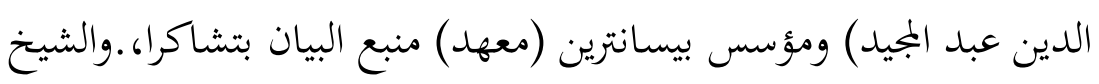

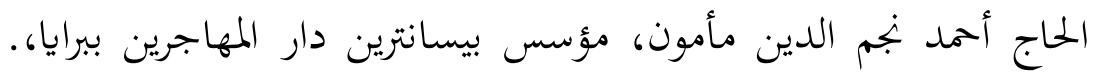

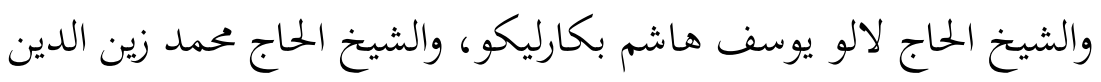

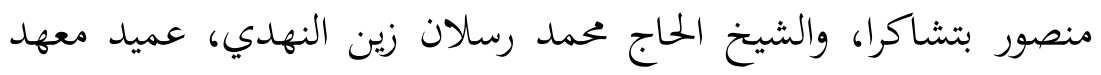

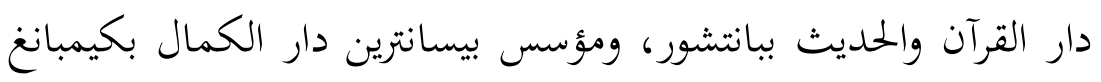

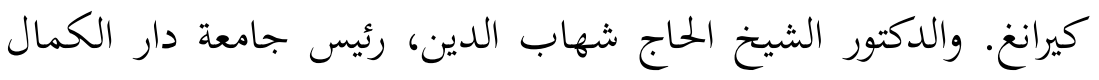

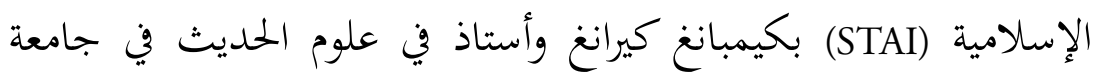

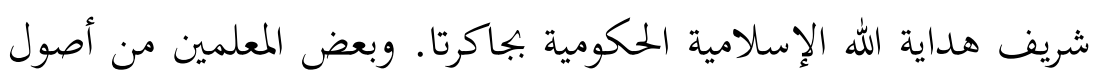

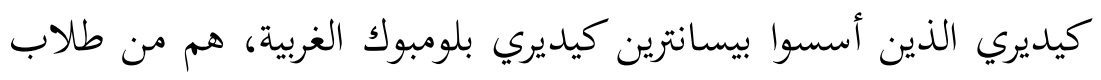
الشيخ ياسين الفداني (Ruslan Zain 2019).

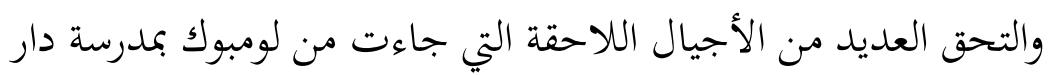

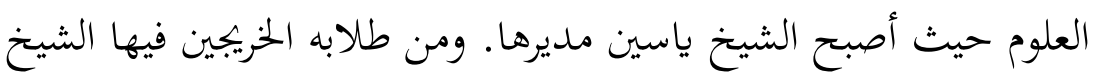

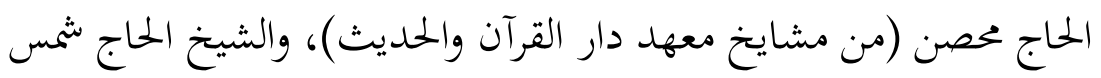

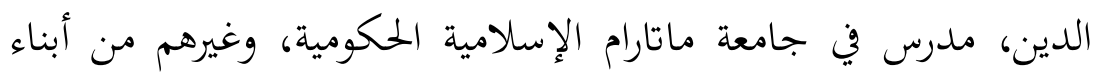

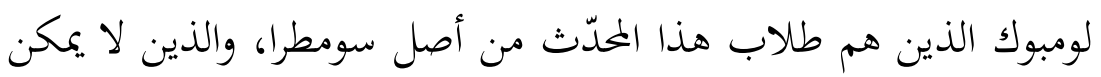

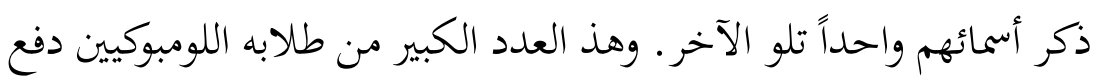

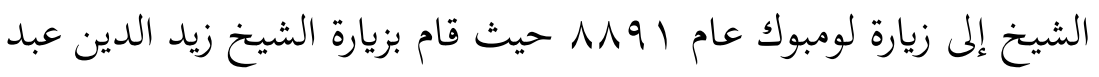

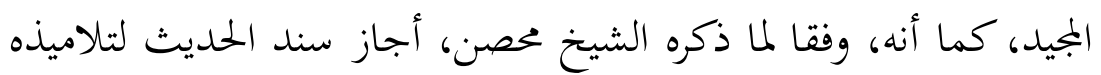


اللومبوكيين في الساحة الأمامية لبسانترين المجاهدين ببانتشور Mukhsan)

وكان الشيخ ياسن، أثناء لقائه بالشيخ زين الدين عبد المجيد، طلب

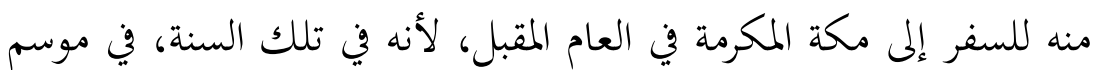

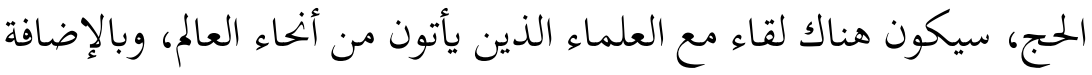

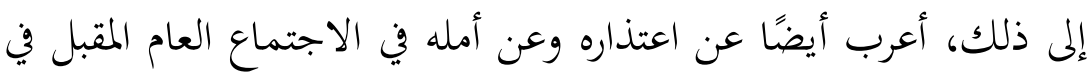

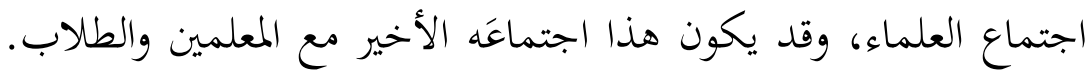

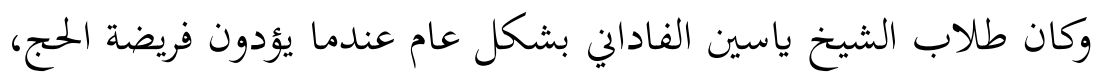

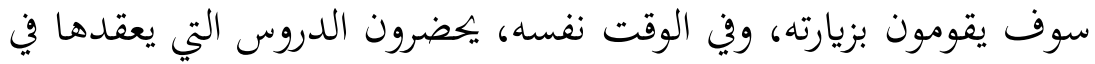

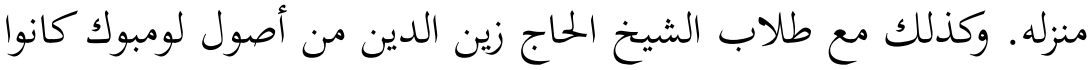

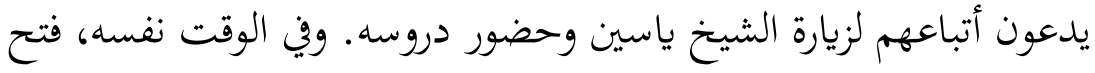

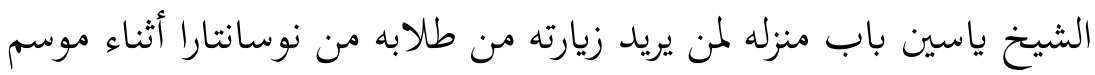

الحج (TGH. Taufik dan TGH. Yusuf Makmun 2019) وهكذا تواصل الأجيال اللاحقة هذه العلاقات. وبالنسبة لمجتمع ساسك، الحاك،

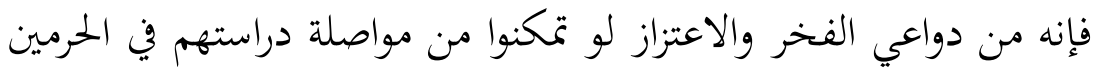

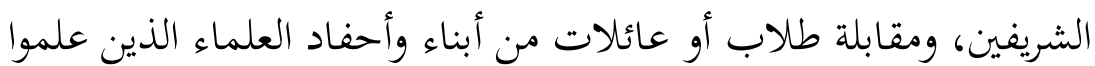

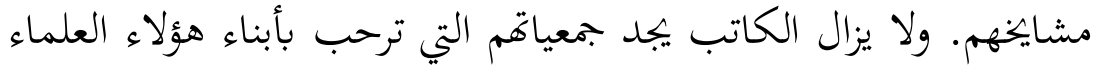

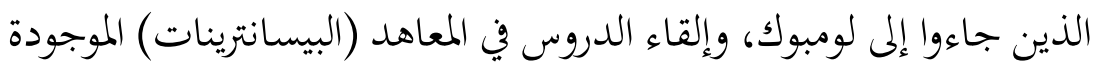

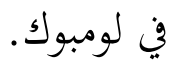

\section{خاتمة}

لقد أثبت هذا المقال أن العلاقات المتينة والمكثفة بين لومبوك وسومطرا قد أقيمت منذ القرن الثاني عشر إلى القرن العشرين، وهذه العلاقات العات التئي

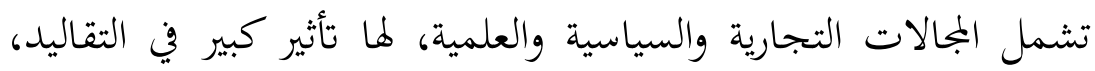


والثقافات، والمخطوطات القديمة، والفهم الديني عند مجتمع ساساك. وقد

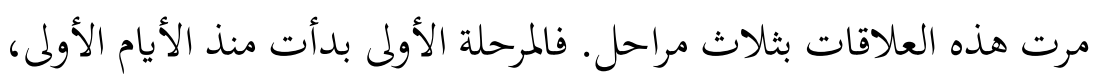

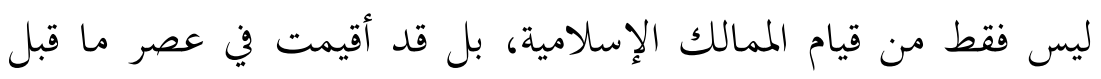
الممالك الإسلامية في نوسانتارا. وفي ذلك الوقت كانت لومبوك برئاسة برابو نياكراواتي، الذي أقام

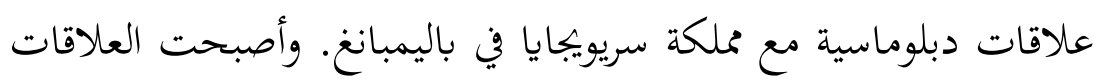

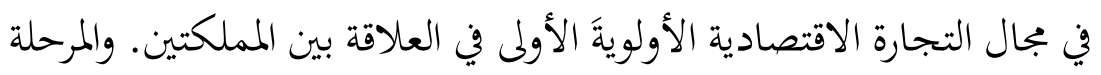
الثانية هي علاقات لومبوك مع سومطرا في عصر تقدم المملكة الإسلامية، حيث أقام ملك لومبوك علاقات مع ملوك الملايو في سومطرا. ويتضح هذا من خلال اكتشاف العديد من البقايا الأثرية مثل شواهد قبر آتشيه في بجمع مقبرة سيالابارانغ والتي تأخذ شكل أجنحة بوكران، كما تم العثور

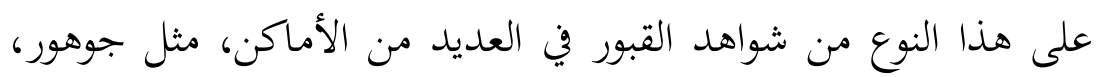

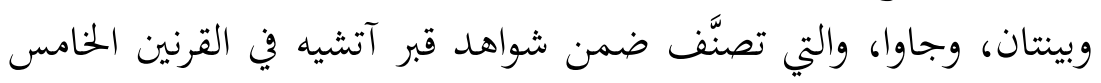
عشر والسادس عشر .

أما المرحلة الثالثة لعلاقات الشبكات الفكرية فهي العلاقة التي أسسها العلماء من أصول لومبوك مع العلماء من أصول سومطرا في الحرمين الشريفين. وتم بناء هذه العلاقة من قبل المقيمين من أصول نوسانتارا الذين التقوا في

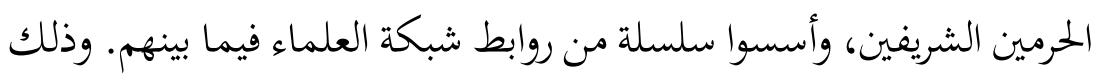
في شكل العلاقات بين التلميذ والشيخ أو العكس، أو أولئك الذين تعلموا

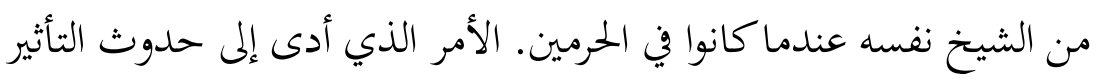
والتأثر فيما بين هاتين المنطقتين. وقد تعلم الشيخ الحاج عمر بونتيمبي من

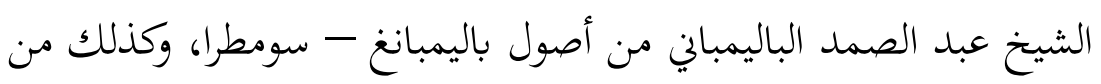

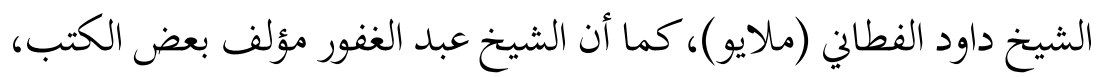
ومرشد الطريقة، كانت له علاقة مع العلماء من أصول الملايو. 
وباء فيما بعد الشيخ الحاج عمر كيلايو الذي كان لديه تلاميذ من

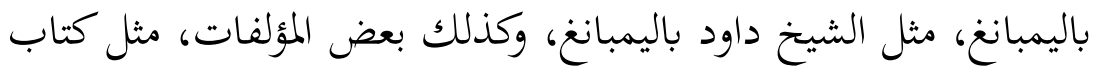

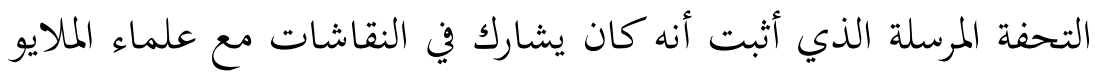

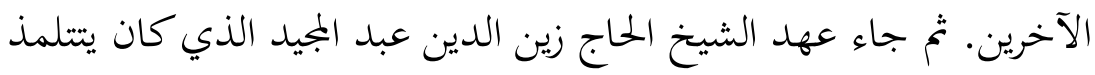

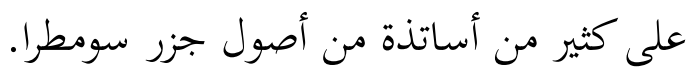

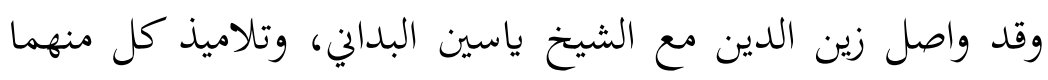

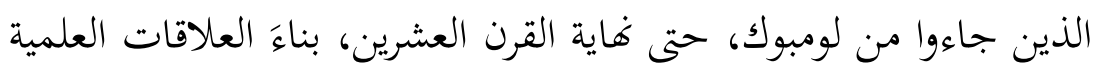

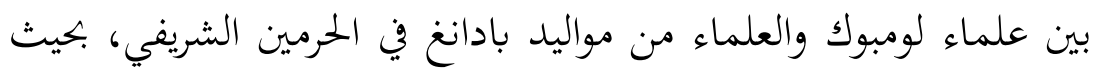
استمرت هذه العلاقات فيما بين الأجيال اللاحقة.

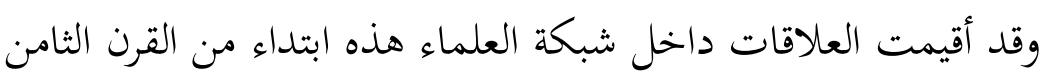

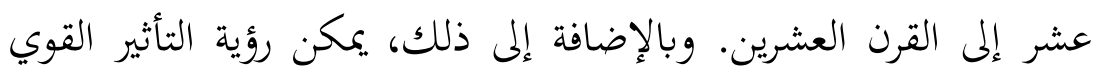

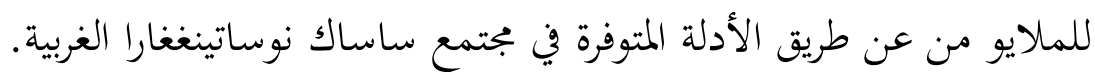

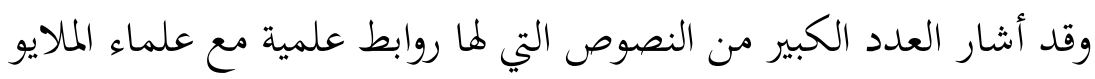
إلى أن الملايو لها تأثير كبير في بجتمع الساساك. 


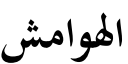

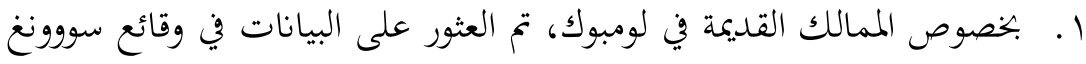

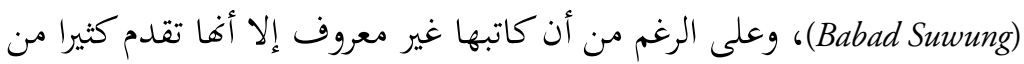

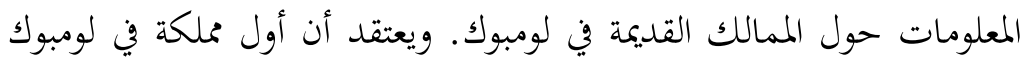

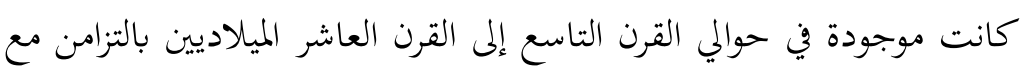

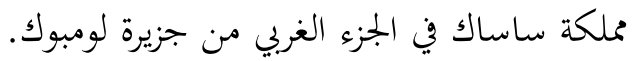

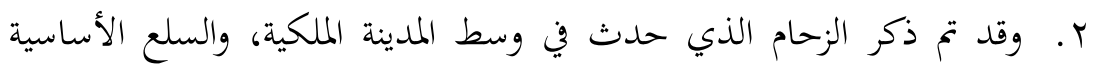

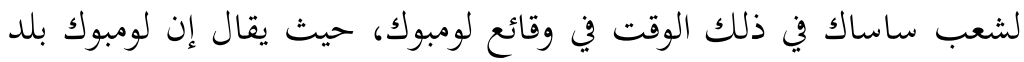

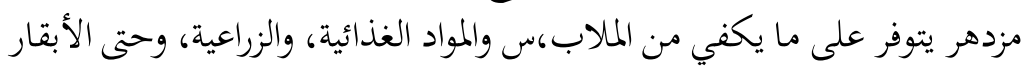

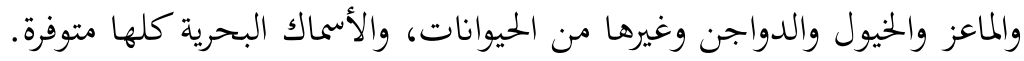

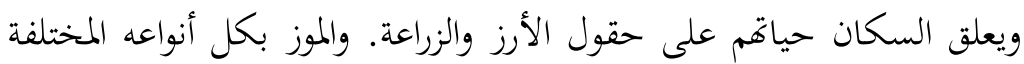

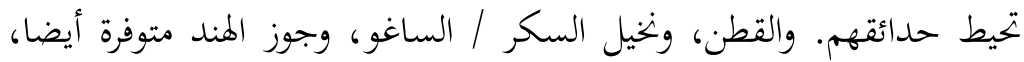

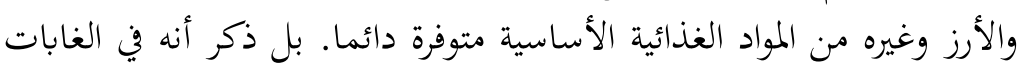

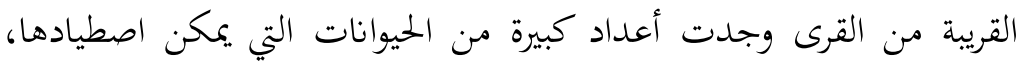

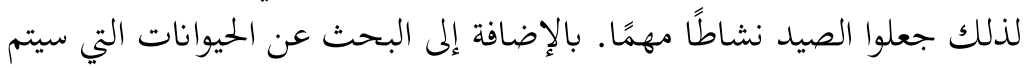

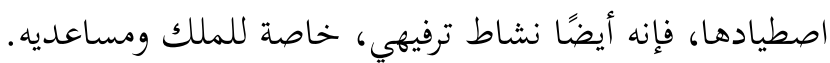

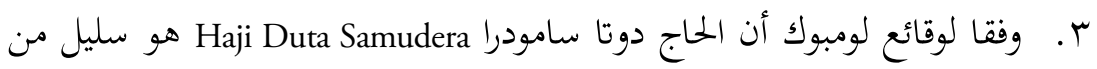

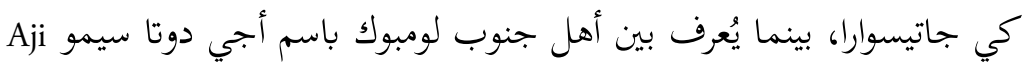
Duta Semu

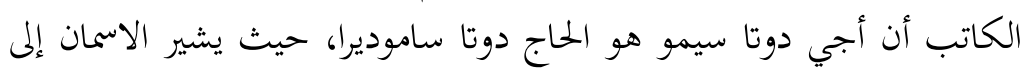

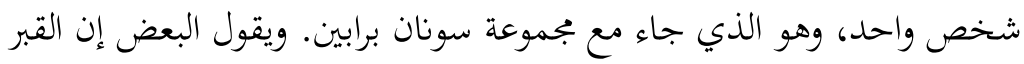

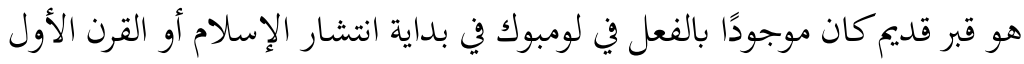

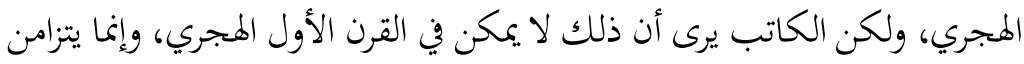

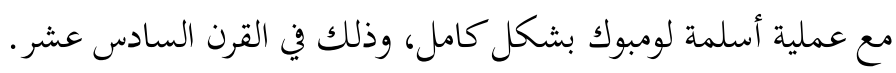

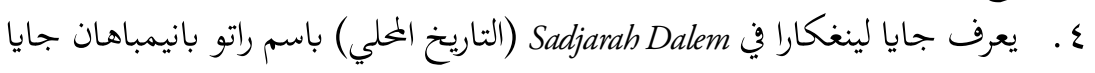

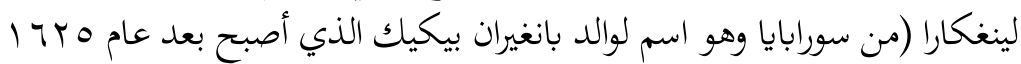

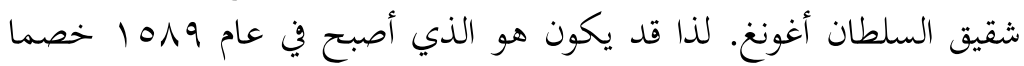

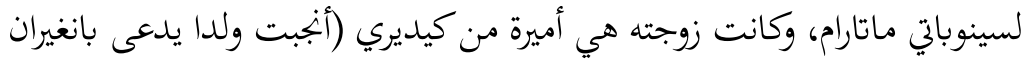
بيكيك)، وهي من أقرباء الملك في مدينة ماديون التي كانت أصولها من من محلكة ميكة ديماك. 


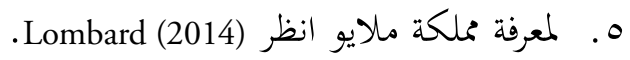

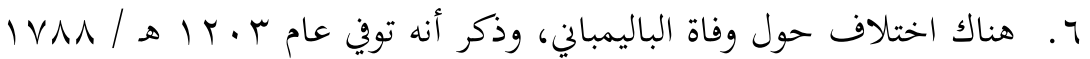
م، انظر (2018, 95) V. انظر كتاب هداية السالكمئ لعبد الصمد الباليمباني الذي جمع الحاج لالو زكريا، من سلالة الشيخ عمر بونتيمبي

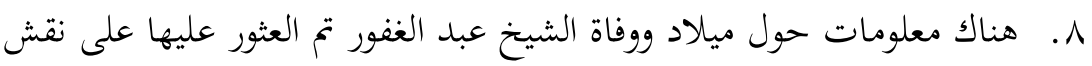

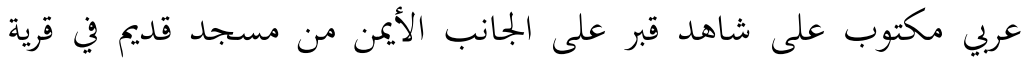

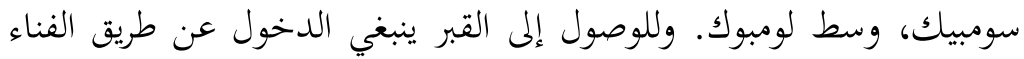
الأمامي للمنزل الذي يسكنه حاليا سلالته.

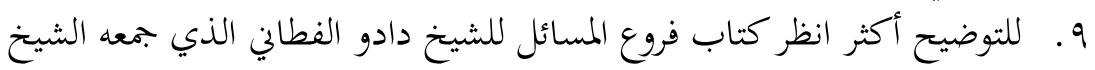
عمران - بينوجاك. • ا.كتاب المعرج للشيخ الحاج عبد الغفور الذي جمعه أحد أسرته، الشيخ علي ماسنون سومبيكاه.

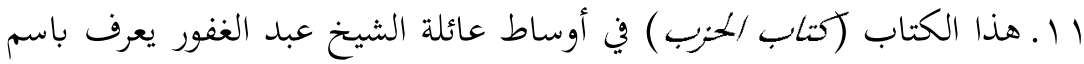

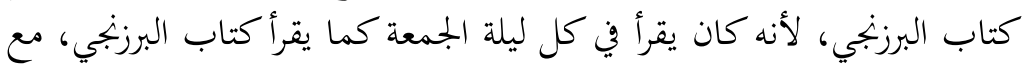

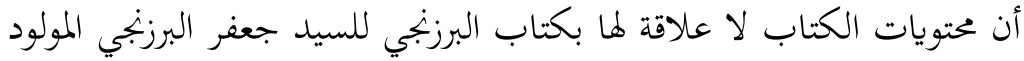
في مصر. ץ ا. لا يوجد أي توضيح حول المراد باسم 》ولي القطب) . وهو عند علماء الطريقة

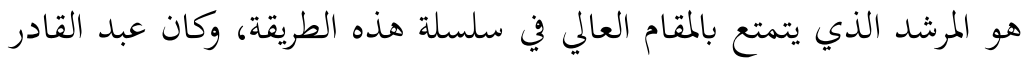

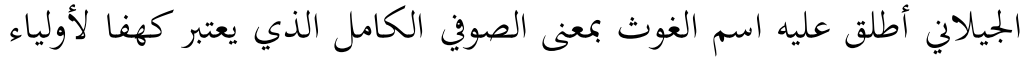

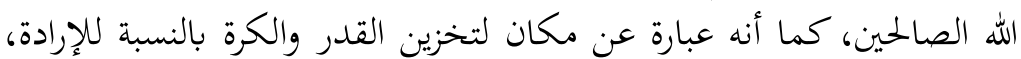

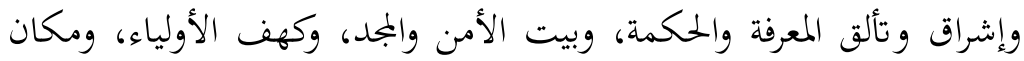
إشراق نور الله (Utama 2016, 42).

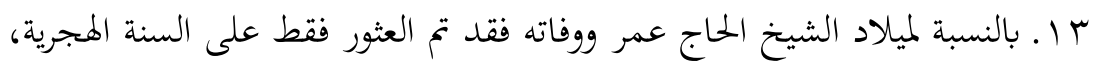

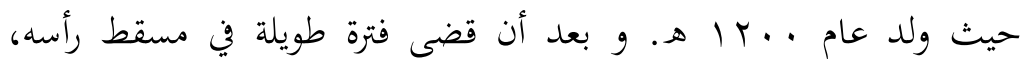

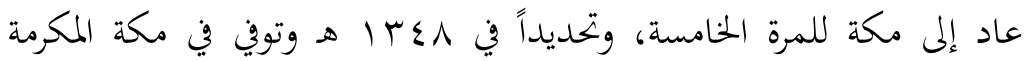

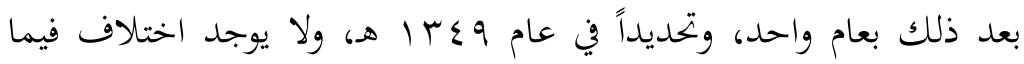

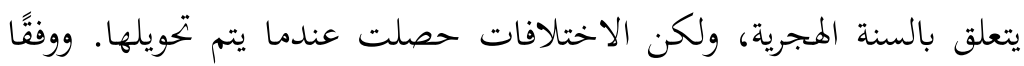

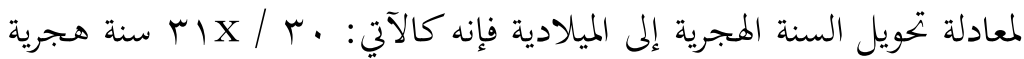

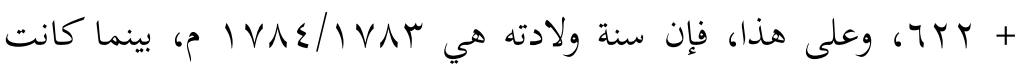




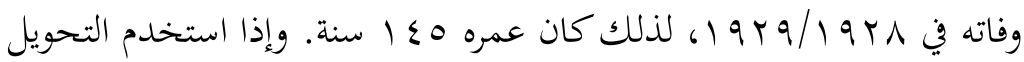

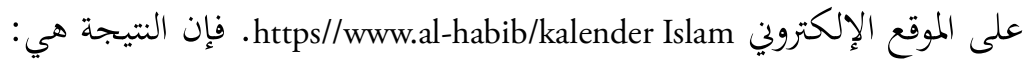

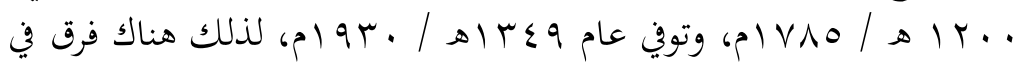

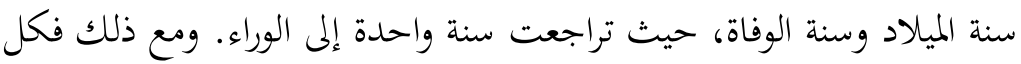

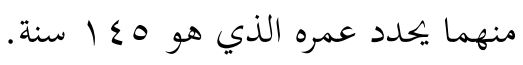

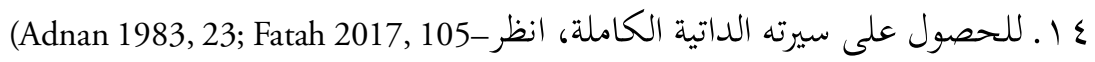

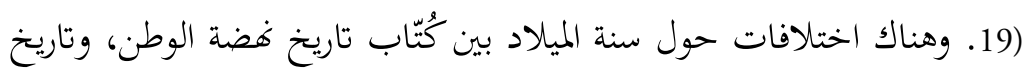

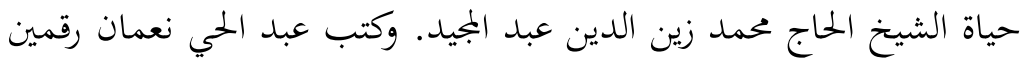

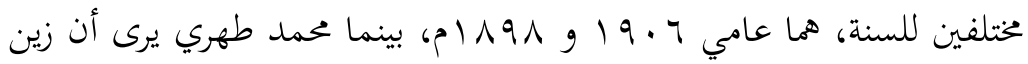
الدين من مواليد 11/99 م. انظر (Thohri 2015, 30).

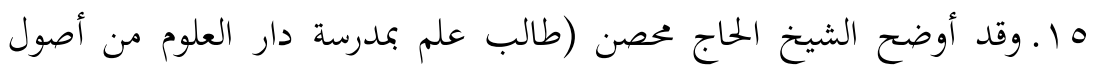

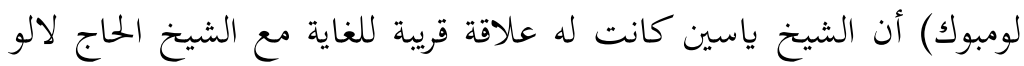

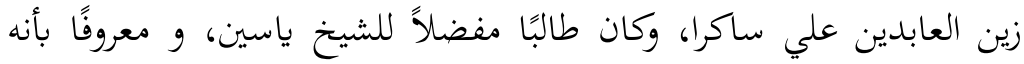

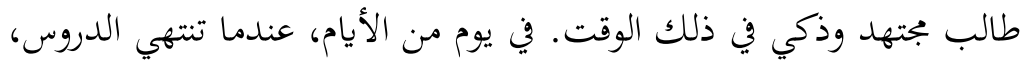

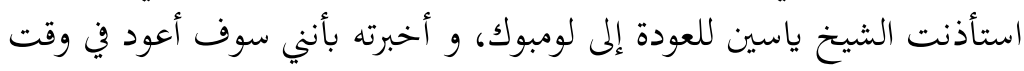

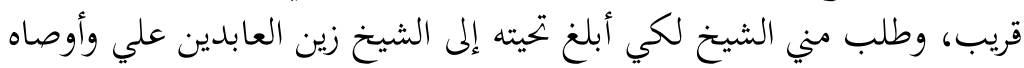

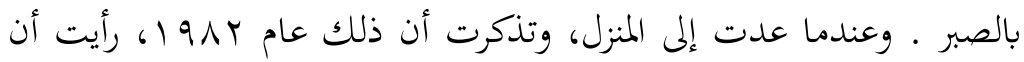

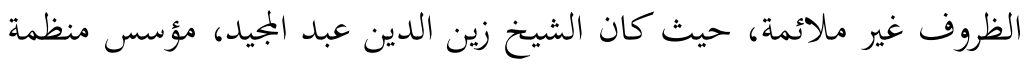

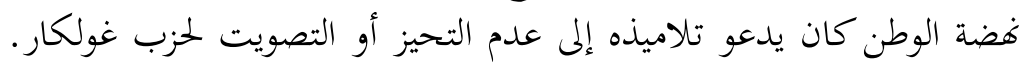

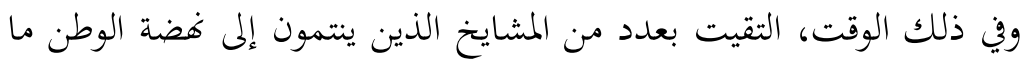

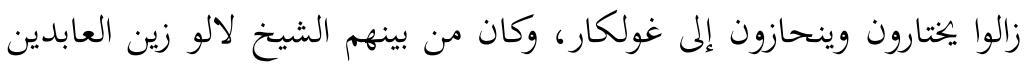

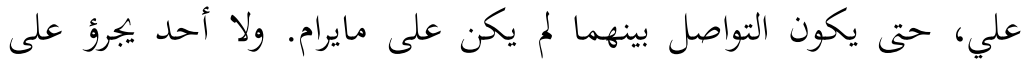

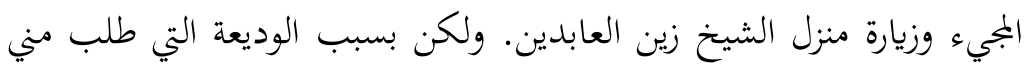

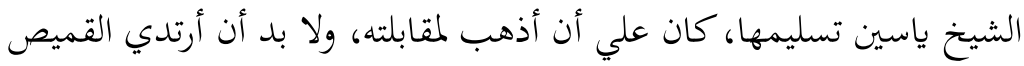

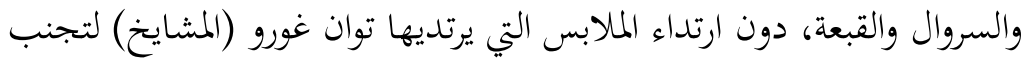

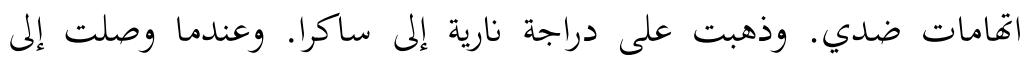

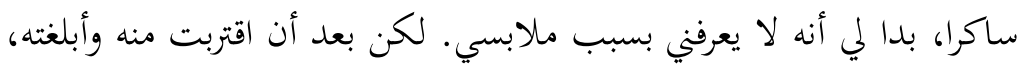

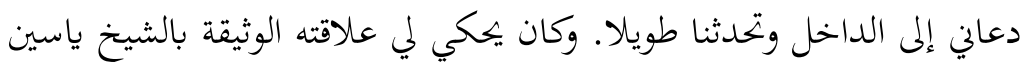
الفاداني. ويبدو أن الشيخ ياسين شعر بالقلق إزاء الصعوبات التي تواجه تلميذه. 


\section{المراجع}

Abdullah. 1990. Syaikh Daud Bin Abdullāh Al-Fathani: Ulama Dan Pengarang Terulung Asia Tenggara. Kuala Lumpur: Hizbi.

- 2015. Syaikh Abdus-Shamad Al-Palimbani. Yogyakarta: Pustaka Pesantren.

Adnan, Afifuddin. 1983. Diktat Pelajaran Ke-NW-an UntukMadrasah Dan Sekolah Menengah NW. Pancor: Biro Dakwah Yayasan Pendidikan Hamzanwadi.

Alhamuddin. 2018. "Abd Shamad Al-Palimbani's Islamic Education Concept: Analysis of Kitab Hidayah Al-Sālikin Fi Suluk Māsāāk Lil Muttāqin.” Qudus International Journal of Islamic Studies 6(1): 89-102.

Ambary, Hasan Muarif. 1998. Menemukan Peradaban: Jejak Arkeologis Dan Historis Islam Indonesia. Jakarta: Logos Wacana Ilmu.

Amin, Kasma F. 2017. Para Tawanan Perang: Kisah Syekh Yusuf Al Makassari Dan Arung Palakka. Makassar: Celebes Media Perkasa.

Azhar, Lalu M., and Lalu M. Shaleh Tsalis. 2003. Tuan Guru Lopan; Waliyullah Dengan Kiprah Dan Karomahnya. Mataram: Yayasan Pondok Pesantren asSalehiyah Lopan.

Azra, Azyumardi. 2005. Jaringan Ulama Timur Tengah Dan Kepulauan Nusantara Abad XVII- XVIII: Akar Pembaharuan Islam Di Indonesia. Jakarta: Kencana.

Azra, Azyumardi, and Oman Fathurahman. 2005. Jaringan Ulama Dalam Ensiklopedi Tematik Dunia Islam. Jakarta: Ichtiar Baru van Hoeve.

Budiwanti, Erni. 1999. Islam Sasak: Wetu Telu Versus Waktu Lima. Yogyakarta: LKiS.

Coede's, George. 2015. Asia Tenggara Masa Hindu-Buddha. Jakarta: KPG-EFEO, Forum Jakarta-Paris Pusat penelitian Arkeologi Nasional.

Duli, Akin et al. 2013. Monumen Islam Di Sulawesi Selatan. Makassar: Balai Pelestarian Cagar Budaya Makassar.

Fakihuddin, Lalu. 2018. "Relasi Antara Budaya Sasak Dan Islam: Kajian Berdasarkan Perspektif Folklor Lisan Sasak.” SeBaSa 1(2): 89-105.

Fatah, Abdul. 2017. Dari Nahdlatul Wathan Untuk Indonesia. Mataram: Dinas Sosial NTB.

Graaf, H.J. de. 1941. "Lombok in de 17e Eeuw." Djawa XXI.

Graaf, H.J. de, and Th. G. Pigeaud. 1986. Kerajaan-Kerajaan Islam Pertama Di Jawa: Kajian Sejarah Politik Abad Ke-15 Dan Ke-16. Jakarta: Graffitipers.

Handayani, Usri Indah. 1997. Peninggalan Sejarah dan Kepurbakalaan Nusa Tenggara Barat. Mataram: Departemen Pendidikan dan Kebudayaan, 
Kantor Wilayah Propinsi Nusa Tenggara Barat, Bagian Proyek Pembinaan Permuseuman Nusa Tenggara Barat.

Haris, Tawalinuddin. 2002. Masuk Dan Berkembangnya Islam Di Lombok Kajian Data Arkeologis Dan Sejarah. Lombok Timur: Yayasan Lentera Utama.

Herman, Lalu Wiramaya, Lalu Wacana, and Sri Marlupi. 1990. Bunga Rampai Kutipan Naskah Lama Dan Aspek Pengetahuannya. Mataram: Depdikbud, Direktorat Jenderal Kebudayaan, Museum Negeri NTB.

Hurgronje, C. Snouck. 1989. "Ulama Jawa Yang Ada Di Makkah Pada Akhir Abad Ke-19.” In Islam Di Asia Tenggara: Perspektif Sejarah, eds. Ahmad Ibrahim, Sharon Shiddique, Yasmin Hussain, and Tan Sri Datuk. Jakarta: LP3ES.

Jamaluddin. 2004. "Islam Sasak Sejarah Sosial Islam Di Lombok." Sekolah Pascasarjana UIN Syarif Hidayatullah Jakarta.

—. 2011a. "Haflat Al-Mawlid al-Nabawī Wa-Qirāat Kitāb al-Barzanjī Fī Mujtama' Sasak: Manẓūrāt Tārīkhīyah.” Studia Islamika 18(2): 347-70.

_. 2011b. "Islam Sasak: Sejarah Sosial Keagamaan Di Lombok (Abad XVIXIX).” Jurnal Indo Islamika 1(1): 63-88.

2011c. Sejarah Sosial Islam Di Lombok Tahun 1740-1935: Studi Kasus Terhadap Tuan Guru. Jakarta: Balitbang dan Diklat Puslitbang Lektur dan Khazanah Keagamaan Kementerian Agama RI.

- 2012. "Kerajaan Dan Perkembangan Peradaban Islam: Telaah Terhadap Peran Istana Dalam Tradisi Pernaskahan Di Lombok.” Manuskripta 2(1): 181-200.

2016. "Abdul Gafur: Keterlibatan Ulama Sasak Dalam Jaringan Ulama (1754-1904).” Al-Qalam 22(1): 49-60.

- 2018. Islamisasi Masyarakat Sasak Dalam Jalur Perdagangan Global. Mataram: Lemlit UIN Mataram.

_. 2019. Jejak-Jejak Arkeologi Islam Di Lombok. Mataram: Sanabil.

Ken, Wong Lin. 1978. "Singapore: Its Growth as an Entrepot Port, 1819-1941.” Journal of Southeast Asian Studies 9(1): 50-84.

Lombard, Denys. 2014. Kerajaan Aceh Zaman Sultan Iskandar Muda (16071636). Forum Jakarta Paris.

Nas, Peter J.M., and Welmoet Boender. 2002. The Indonesia Town Revicited. Singapore: Institute of Southeast Asian Studies.

Nordholt, Henk Schulte. 2008. "Memikir Ulang Historiografi Indonesia." In Perspektif Baru Penulisan Sejarah Indonesia, Jakarta: Yayasan Obor Indonesia, KITLV-Pustaka Larasan.

Patji, Abdul Rahman. 2005. Agama dan Pandangan Hidup: Kajian Tentang Religi 
Lokal Di Bali Dan Lombok. Jakarta: Lembaga Ilmu Pengetahuan Indonesia.

Perret, Daniel, and Kamarudin bin Ab Razak. 1999. Batu Aceh: Warisan Sejarah Johor. École francaise d'Extrême-Orient.

Ras, Johannes Jacobus. 1968. Hikayat Banjar. Leiden: The Hague-Martinus Nijhoff.

Ricklefs, Merle C. 2008. A History of Modern Indonesia since c. 1200. 4th ed. New York: Palgrave Macmillan.

Steenbrink, Karel A. 1984. Beberapa Aspek tentang Islam di Indonesia Abad ke-19. Jakarta: Bulan Bintang.

Sulanam. 2013a. "From 'Sufi Order Ritual' To Indonesian Islam." Journal of Indonesian Islam 7(1): 212-216-216.

Sulanam, Sulanam. 2013b. "From 'Sufi Order Ritual' to Indonesian Islam." Journal of Indonesian Islam 7(1): 212-216-216.

Suryo, Djoko. 2005. "Ekonomi Masa Kesultanan." In Ensiklopedi Tematis Dunia Islam: Asia Tenggara, Jakarta: Ichtiar Baru van Hoeve.

Syam, Nur. 2005. Islam Pesisir. Yogyakarta: LKiS.

Thohri, Muhammad. 2015. Menyusuri Keagungan Cinta Maulana. Mataram: Sanabil.

Tim Penyusun. 1977. Monografi Daerah Nusa Tenggara Barat. Jakarta: Proyek Pengembangan Media Kebudayaan, Departemen P \& K.

Utama, Chandra. 2016. Lentera Para Wali. Jakarta: Guepedia.

Yatim, Othman Mohd. 1987. Batu Aceh: Early Islamic Gravestones in Peninsular Malaysia. Kuala Lumpur: Museum Association of Malaysia.

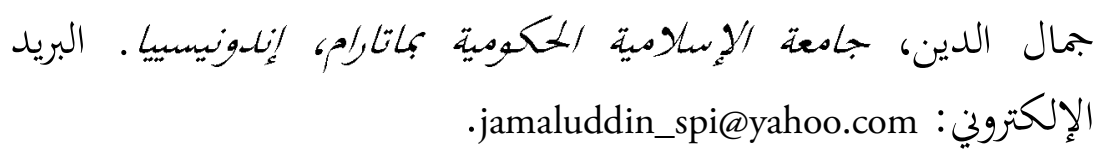




\section{Guidelines}

\section{Submission of Articles}

tudia Islamika, published three times a year since 1994, is a bilingual (English and Arabic), peer-reviewed journal, and specializes in Indonesian Islamic studies in particular and Southeast Asian Islamic studies in general. The aim is to provide readers with a better understanding of Indonesia and Southeast Asia's Muslim history and present developments through the publication of articles, research reports, and book reviews.

The journal invites scholars and experts working in all disciplines in the humanities and social sciences pertaining to Islam or Muslim societies. Articles should be original, research-based, unpublished and not under review for possible publication in other journals. All submitted papers are subject to review of the editors, editorial board, and blind reviewers. Submissions that violate our guidelines on formatting or length will be rejected without review.

Articles should be written in American English between approximately 10.000-15.000 words including text, all tables and figures, notes, references, and appendices intended for publication. All submission must include 150 words abstract and 5 keywords. Quotations, passages, and words in local or foreign languages should 
be translated into English. Studia Islamika accepts only electronic submissions. All manuscripts should be sent in Ms. Word to: http:// journal.uinjkt.ac.id/index.php/studia-islamika.

All notes must appear in the text as citations. A citation usually requires only the last name of the author(s), year of publication, and (sometimes) page numbers. For example: (Hefner 2009a, 45; Geertz 1966, 114). Explanatory footnotes may be included but should not be used for simple citations. All works cited must appear in the reference list at the end of the article. In matter of bibliographical style, Studia Islamika follows the American Political Science Association (APSA) manual style, such as below:

1. Hefner, Robert. 2009a. "Introduction: The Political Cultures of Islamic Education in Southeast Asia," in Making Modern Muslims: The Politics of Islamic Education in Southeast Asia, ed. Robert Hefner, Honolulu: University of Hawai'i Press.

2. Booth, Anne. 1988. "Living Standards and the Distribution of Income in Colonial Indonesia: A Review of the Evidence." Journal of Southeast Asian Studies 19(2): 310-34.

3. Feener, Michael R., and Mark E. Cammack, eds. 2007. Islamic Law in Contemporary Indonesia: Ideas and Institutions. Cambridge: Islamic Legal Studies Program.

4. Wahid, Din. 2014. Nurturing Salafi Manhaj: A Study of Salafi Pesantrens in Contemporary Indonesia. PhD dissertation. Utrecht University.

5. Utriza, Ayang. 2008. "Mencari Model Kerukunan Antaragama." Kompas. March 19: 59.

6. Ms. Undhang-Undhang Banten, L.Or.5598, Leiden University.

7. Interview with K.H. Sahal Mahfudz, Kajen, Pati, June $11^{\text {th }}$, 2007.

Arabic romanization should be written as follows:

Letters: ', $b, t, t h, j, h, k h, d, d h, r, z, s, s h, s, d, t, z, ', g h, f, q, l$, $m, n, h, w, y$. Short vowels: $a, i, u$. long vowels: $\bar{a}, \overline{\mathrm{i}}, \overline{\mathrm{u}}$. Diphthongs: $a w$, ay. Tà marbūtāa: t. Article: al-. For detail information on Arabic Romanization, please refer the transliteration system of the Library of Congress (LC) Guidelines. 
ستوديا إسلاميكا (ISSN 0215-0492; E-ISSN: 2355-6145) مجلة علمية دولية محكمة تصدر عن مركز دراسات الإسلام والمجتمع (PPIM) بجامعة شريف هداية الله الإسلامية الحكومية بجاكرتا، تعنى بدراسة الإسلام في إندونيسيا خاصة وفي جنوب شرقي آسيا عامة. وتستهدف المجلة نشر البحوث العلمية الأصيلة والقضايا المعاصرة حول الموضوع، كما ترحب بإسهامات الباحثين أصحاب التخصصات ذات الصلة. وتخضع جميع الأبحاث المقدمة للمجلة للتحكيم من قبل لجنة مختصة.

تم اعتماد ستوديا إسلاميكا من قبل وزارة البحوث والتكنولوجيا والتعليم العالي بجمهورية إندونيسيا باعتبارها دورية علمية (رقم القرار: 32a/E/KPT/2017).

ستوديا إسلاميكا عضو في CrossRef (الإحالات الثابتة في الأدبيات الأكاديمية) منذ ع ا • ب، وبالتالي فإن جميع المقالات التي نشرتا مرقمة حسب معرّف الوثيقة الرقمية (DOI). ستوديا إسلاميكا بجلة مفهرسة في سكوبس (Scopus) منذ .ب مايو 0 . ب.

$$
\begin{aligned}
& \text { قيمة الاشتر الك السنوي خارج إندونيسيا: }
\end{aligned}
$$

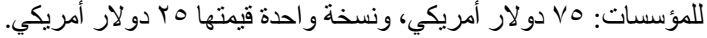

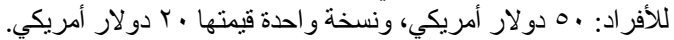

$$
\begin{aligned}
& \text { والقيمة لا تشمل نفقة الإرسال بالبريد الجوي. ونسي. }
\end{aligned}
$$

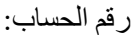

$$
\begin{aligned}
& \text { خارج إندونيسيا (دولار أمريكي): ابن }
\end{aligned}
$$

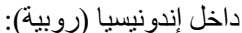

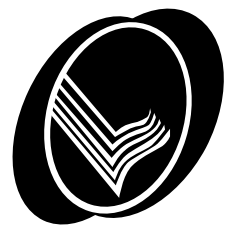




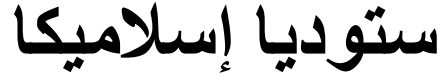 \\ مجلة إندونيسيا للار اسات الإسلامية}

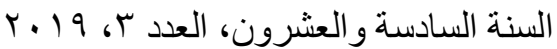

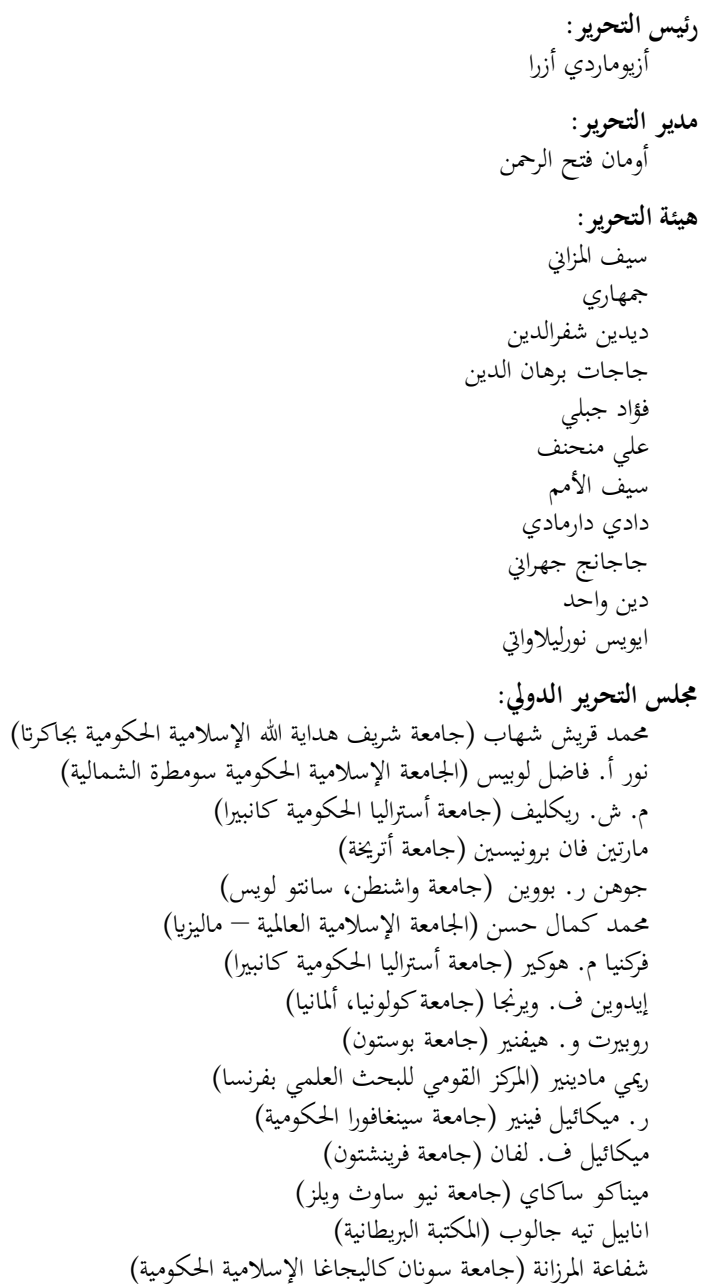

مساعد هيئة التحرير:

تيستريونو

محمد نداء فضلان

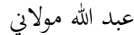

مراجعة اللغة الإنجليزية:

بنيمن ج. فريمان

دانيل فتريون

موسى بتول

مراجعة اللغة العربية:

توباغوس أدي أسناوي

تصميم الغلاف:

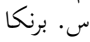





\section{لالتوايا السال|مسيا}




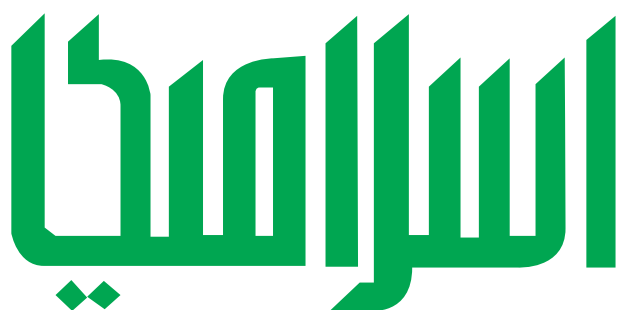

السنة السادسة والعشرون، العدد ب، 9 1 بـ

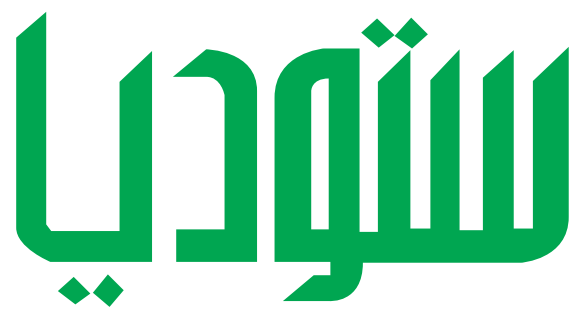

بجلة إنلدونيسية للدراسات الإسلامية

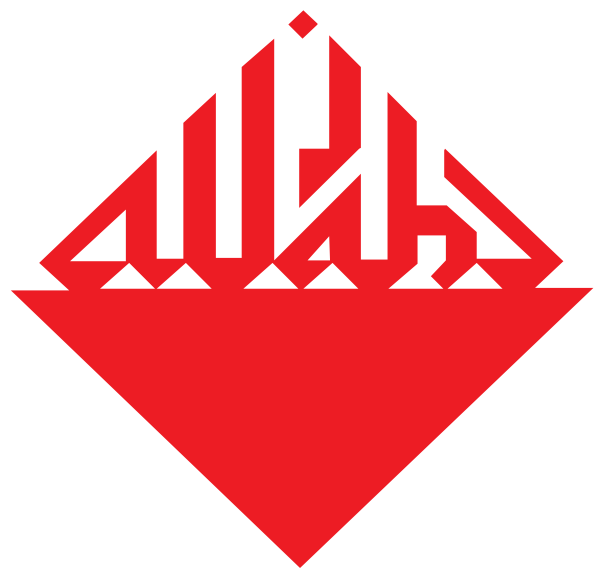

الشبكائ الاجتماعية والمنحرية

Sumatera y Lombok بيلن هسلمين

كاسة كيم تهنة وهنطوط Sasak جمال الدين 